Prepared in cooperation with the Allegheny County Sanitary Authority

\title{
Calibration of a Two-Dimensional Hydrodynamic Model for Parts of the Allegheny, Monongahela, and Ohio Rivers, Allegheny County, Pennsylvania
}

Scientific Investigations Report 2013-5145 



\section{Calibration of a Two-Dimensional Hydrodynamic Model for Parts of the Allegheny, Monongahela, and Ohio Rivers, Allegheny County, Pennsylvania}

By John W. Fulton and Chad R. Wagner

Prepared in cooperation with the

Allegheny County Sanitary Authority

Scientific Investigations Report 2013-5145 


\title{
U.S. Department of the Interior \\ SALLY JEWELL, Secretary
}

\section{U.S. Geological Survey \\ Suzette M. Kimball, Acting Director}

\author{
U.S. Geological Survey, Reston, Virginia: 2014
}

For more information on the USGS — the Federal source for science about the Earth, its natural and living resources, natural hazards, and the environment, visit http://www.usgs.gov or call 1-888-ASK-USGS.

For an overview of USGS information products, including maps, imagery, and publications, visit http://WWW.usgs.gov/pubprod

To order this and other USGS information products, visit http://store.usgs.gov

Any use of trade, product, or firm names is for descriptive purposes only and does not imply endorsement by the U.S. Government.

Although this report is in the public domain, permission must be secured from the individual copyright owners to reproduce any copyrighted materials contained within this report.

Suggested citation:

Fulton, J.W., and Wagner, C.R., 2014, Calibration of a two-dimensional hydrodynamic model for parts of the Allegheny, Monongahela, and Ohio Rivers, Allegheny County, Pennsylvania: U.S. Geological Survey Scientific Investigations Report 2013-5145, 41 p., http://dx.doi.org/10.3133/sir20135145.

ISSN 2328-0328 (online) 


\section{Contents}

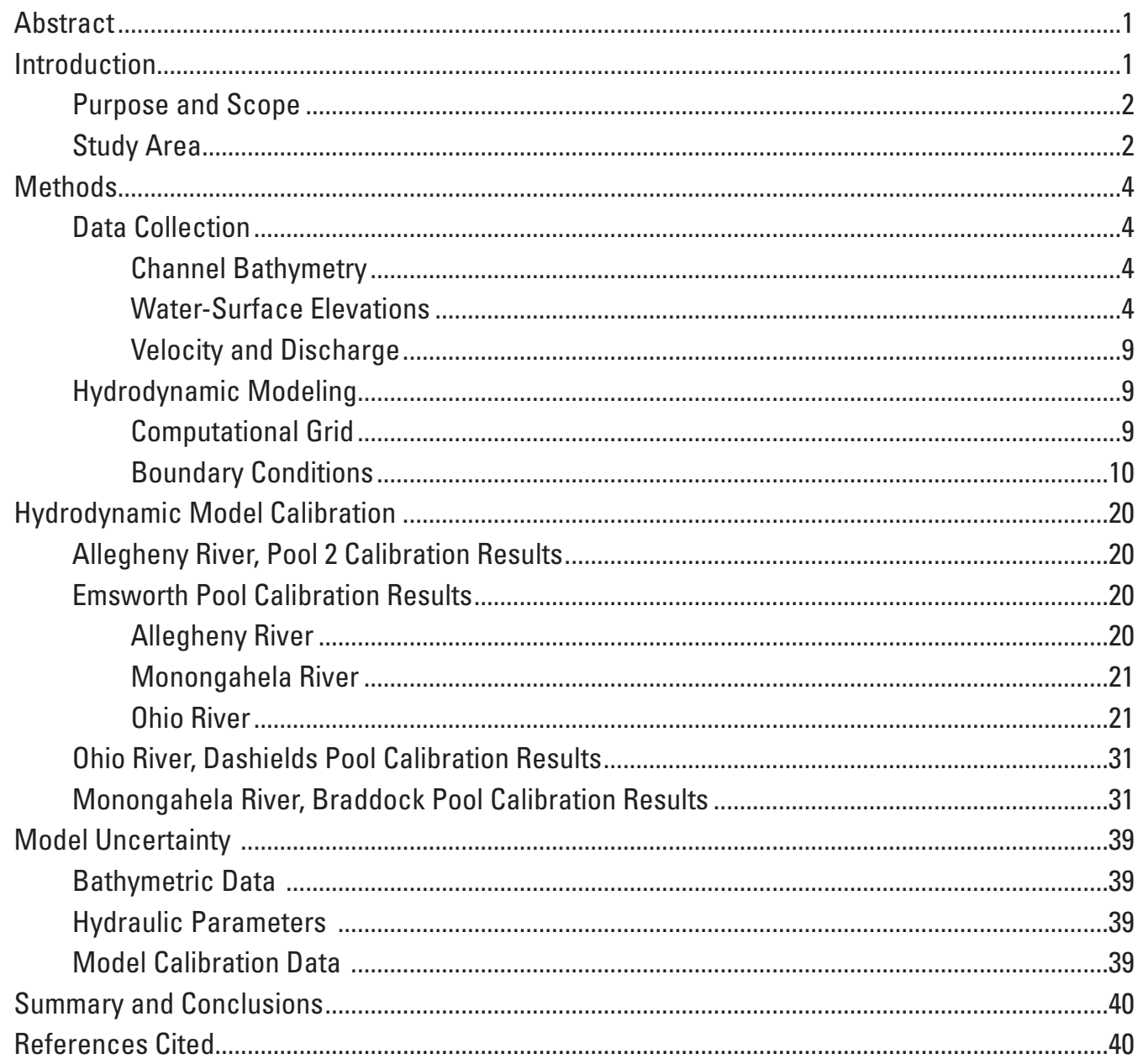




\section{Figures}

1. Map showing study area and locations of U.S. Army Corps of Engineers locks and dams on the Allegheny, Monongahela, and Ohio Rivers in Allegheny County, Pennsylvania.....3

2. Map showing location of U.S. Geological Survey streamgages in Allegheny County, Pennsylvania

3. Map showing location of bathymetric transects and locks and dams on the Allegheny River in Allegheny County, Pennsylvania...

4. Map showing location of bathymetric transects and locks and dams on Monongahela River in Allegheny County, Pennsylvania.

5. Map showing location of bathymetric transects and locks and dams on Ohio River in Allegheny County, Pennsylvania.

6. Map showing location of high-flow velocity transects and locks and dams on the Allegheny River in Allegheny County, Pennsylvania. 10

7. Map showing location of low-flow velocity transects and locks and dams on the Allegheny River in Allegheny County, Pennsylvania...

8. Map showing location of high-flow velocity transects and locks and dams on the Monongahela River in Allegheny County, Pennsylvania

9. Map showing location of high-flow velocity transects from Point State Park to the Ohio River locks and dams on the Ohio River in Allegheny County, Pennsylvania .........13

10. Map showing location of low-flow velocity transects from the Ohio River locks and dams to the Dashields lock and dam on the Ohio River in Allegheny County, Pennsylvania

11. Map showing location of high-flow velocity transects from the Ohio River locks and dams to the Dashields lock and dam on the Ohio River in Allegheny County, Pennsylvania

12. Map showing example of the finite-element grid configuration for the hydrodynamic model of the Allegheny, Monongahela, and Ohio Rivers in Allegheny County, Pennsylvania

13. Graphs showing measured and simulated velocity distributions at cross-sections 17 and 19 directly downstream from Sycamore and Nine-Mile Islands on the Allegheny River, Pool 2 model segment for $A$, high-flow and $B$, low-flow conditions near Pittsburgh, Pennsylvania.

14. Graph showing measured and simulated high-flow velocity vectors at crosssection 17 downstream from Sycamore and Nine-Mile Islands on the Allegheny River, Pool 2 model segment near Pittsburgh, Pennsylvania .....

15. Graphs showing measured and simulated velocity distributions at cross-sections 4 and 5 directly downstream from Herrs Island on the Allegheny River, Emsworth Pool model segment for $A$, high-flow and $B$, low-flow conditions near Pittsburgh, Pennsylvania .....

16. Graph showing measured and simulated high-flow velocity vectors at cross-section 4 downstream from Herrs Island on the Allegheny River, Emsworth Pool model segment near Pittsburgh, Pennsylvania

17. Graph showing measured and simulated velocity distributions at cross-section 7 on the Monongahela River, Emsworth Pool model segment for high-flow conditions near Pittsburgh, Pennsylvania

18. Graph showing measured and simulated velocity distributions at cross-section 19 on the Monongahela River, Emsworth Pool model segment for high-flow conditions near Pittsburgh, Pennsylvania 
19. Graph showing measured and simulated high-flow velocity vectors at cross-section 19 on the Monongahela River, Emsworth Pool model segment near Pittsburgh,

Pennsylvania .....

20. Graph showing measured and simulated velocity distributions at cross-section 9 directly upstream from Brunot Island on the Ohio River, Emsworth Pool model segment for high-flow conditions near Pittsburgh, Pennsylvania.

21. Graphs showing measured and simulated velocity distributions at cross-sections 3 and 10 directly upstream from Neville and Davis Islands on the Ohio River, Emsworth Pool model segment for $A$, high-flow and $B$, low-flow conditions near Pittsburgh, Pennsylvania ......

22. Graph showing measured and simulated high-flow velocity vectors at cross-section 9 upstream from Brunot Island on the Ohio River, Emsworth Pool model segment near Pittsburgh, Pennsylvania.

23. Graph showing measured and simulated high-flow velocity vectors at crosssections 1, 2, and 3 upstream from Neville and Davis Islands on the Ohio River, Emsworth Pool model segment near Pittsburgh, Pennsylvania .

24. Graphs showing measured and simulated velocity distributions at cross-sections 9 and 2 directly downstream from Neville Island on the Ohio River, Dashields Pool model segment for $A$, high-flow and $B$, low-flow conditions near Pittsburgh, Pennsylvania .....

25. Graph showing measured and simulated high-flow velocity vectors at crosssection 9 downstream from Neville Island on the Ohio River, Dashields Pool model segment near Pittsburgh, Pennsylvania . 


\section{Tables}

1. Summary of the upstream inflow boundary conditions used for calibration of each model segment.

2. Summary of streamflow statistics at four U.S. Geological Survey continuous-record streamgaging stations, October 1, 1968 to September 30, 2004, in the Allegheny, Monongahela, and Ohio Rivers in Allegheny County, Pennsylvania

3. Characteristics of U.S. Army Corps of Engineers locks and dams in the Allegheny, Monongahela, and Ohio Rivers in Allegheny County, Pennsylvania

4. Summary of water-surface elevation calibration results for the Allegheny River, Pool 2 model segment, in Allegheny County, Pennsylvania

5. Summary of flow-split calibration results for islands in the Allegheny River, Pool 2 model segment, in Allegheny County, Pennsylvania ...

6. Statistical summary of measured and simulated velocities for the Allegheny River, Pool 2 model segment, in Allegheny County, Pennsylvania

7. Summary of water-surface-elevation calibration results in the Allegheny, Monongahela, and Ohio Rivers, Emsworth Pool model segment, in Allegheny County, Pennsylvania

8. Summary of flow-split calibration results around Herrs Island in the Allegheny River, Emsworth Pool model segment, in Allegheny County, Pennsylvania ..

9. Statistical summary of velocity-calibration results in the Allegheny, Monongahela, and Ohio Rivers, Emsworth Pool model segment, in Allegheny County,

Pennsylvania

10. Summary of flow-split calibration for islands in the Ohio River, Emsworth Pool model segment, in Allegheny County, Pennsylvania

11. Summary of water-surface elevation calibration for the Dashields Pool model segment, in Allegheny County, Pennsylvania.

12. Statistical summary of velocity calibration for the Dashields Pool model segment, in Allegheny County, Pennsylvania. 


\section{Conversion Factors and Datums}

\begin{tabular}{lcl}
\multicolumn{1}{l}{ Inch/Pound to SI } & & \\
\hline & Bultiply & \multicolumn{1}{c}{ To obtain } \\
\hline foot $(\mathrm{ft})$ & Length & \\
mile $(\mathrm{mi})$ & 0.3048 & meter $(\mathrm{m})$ \\
\hline & 1.609 & kilometer $(\mathrm{km})$ \\
\hline square mile $\left(\mathrm{mi}^{2}\right)$ & Area & hectare $(\mathrm{ha})$ \\
\hline & 259.0 & \\
\hline cubic foot per second $\left(\mathrm{ft}^{3} / \mathrm{s}\right)$ & Flow rate & cubic meter per second $\left(\mathrm{m}^{3} / \mathrm{s}\right)$ \\
\hline
\end{tabular}

Vertical coordinate information is referenced to North American Vertical Datum of 1988 (NAVD 88).

Horizontal coordinate information is referenced to the North American Datum of 1983 (NAD 83).

Concentrations of bacteria in water are given in colonies per 100 milliliters (col/100 mL), which is the same as colony forming units per 100 milliliters (CFU/100 mL). 



\title{
Calibration of a Two-Dimensional Hydrodynamic Model for Parts of the Allegheny, Monongahela, and Ohio Rivers, Allegheny County, Pennsylvania
}

\author{
By John W. Fulton and Chad R. Wagner
}

\begin{abstract}
The U.S. Geological Survey (USGS), in cooperation with the Allegheny County Sanitary Authority, developed a validated two-dimensional Resource Management Associates2 (RMA2) hydrodynamic model of parts of the Allegheny, Monongahela, and Ohio Rivers (Three Rivers) to help assess the effects of combined sewer overflows (CSOs) and sanitary sewer overflows (SSOs) on the rivers. The hydrodynamic model was used to drive a water-quality model of the study area that was capable of simulating the transport and fate of fecal-indicator bacteria and chemical constituents under openwater conditions.

The study area includes 14 tributary streams and parts of the Three Rivers where they enter and exit Allegheny County, an area of approximately 730 square miles $\left(\mathrm{mi}^{2}\right)$. The city of Pittsburgh is near the center of the county, where the Allegheny and Monongahela Rivers join to form the headwaters of the Ohio River. The Three Rivers are regulated by a series of fixed-crest dams, gated dams, and radial (tainter) gates and serve as the receiving waters for tributary streams, CSOs, and SSOs.
\end{abstract}

The RMA2 model was separated into four individual segments on the basis of the U.S. Army Corps of Engineers navigational pools in the study area (Dashields; Emsworth; Allegheny River, Pool 2; and Braddock), which were calibrated individually using measured water-surface slope, velocity, and discharge during high- and low-flow conditions. The model calibration process included the comparison of water-surface elevations at five locations and velocity profiles at more than 80 cross sections in the study area. On the basis of the calibration and validation results that included water-surface elevations and velocities, the model is a representative simulation of the Three Rivers flow patterns for discharges ranging from 4,050 to 47,400 cubic feet per second ( $\left.\mathrm{ft}^{3} / \mathrm{s}\right)$ on the Allegheny River, 2,550 to $40,000 \mathrm{ft}^{3} / \mathrm{s}$ on the Monongahela River, and 10,900 to $99,000 \mathrm{ft}^{3} / \mathrm{s}$ on the Ohio River. The Monongahela River was characterized by unsteady conditions during low and high flows, which affected the calibration range.
The simulated low-flow water-surface elevations typically were within 0.2 feet ( $\mathrm{ft}$ ) of measured values, whereas the simulated high-flow water-surface elevations were typically within $0.3 \mathrm{ft}$ of the measured values. The mean error between simulated and measured velocities was less than $0.07 \mathrm{ft} / \mathrm{s}$ for low-flow conditions and less than $0.17 \mathrm{ft} / \mathrm{s}$ for high-flow conditions.

\section{Introduction}

Sewer overflows, a mixture of dilute raw sewage and urban runoff, occur during dry and wet weather and are attributed to malfunctioning conveyance systems or hydraulic overloads caused by excess precipitation. The water-quality constituents of interest may include suspended solids, biochemical oxygen demand (BOD), chloride, nutrients, fecalindicator bacteria, and other chemicals (National Research Council, 2005). Concentrations of fecal coliform (FC) in parts of the Ohio, Allegheny, and Monongahela Rivers (referred to in this report as "Three Rivers") in Allegheny County, Pennsylvania, typically exceed the Pennsylvania water-quality standard (WQS) of 200 colony forming units (col) per 100 milliliters (mL) mandated in Pennsylvania Code $25 \$ 93.7$ (Pennsylvania Code, Title 25), which promulgates that from May 1 through September 30, the maximum concentration shall not exceed a geometric mean of $200 \mathrm{col} / 100 \mathrm{~mL}$ for five consecutive samples in a 30-day period. For the remainder of the year, maximum $\mathrm{FC}$ levels are required to be less than a geometric mean of $2,000 \mathrm{col} / \mathrm{mL}$ for a minimum of five consecutive samples collected on different days during a 30-day period. Monitoring data reported for the Allegheny and Monongahela Rivers indicate concentrations of FC generally are highest in the summer, when WQSs are the most stringent (Fulton and Buckwalter, 2004). The Allegheny County Health Department (ACHD) routinely issues river-water advisories and warnings to discourage water-contact activities following summer rainfall events. The water quality in the Three Rivers is influenced by a number of sources, including point (com- 
bined/sanitary sewers and tributaries) and nonpoint sources (failing or illicitly connected septic tanks, animal/wildlife waste, stormwater runoff).

The hydrodynamic character of the Three Rivers is dominated by the operation of several U.S. Army Corps of Engineers (USACE) reservoirs, locks, and dams. Controlled releases from the USACE reservoirs serve a variety of purposes and vary by site; however, the primary purposes of the reservoirs are flood control, low-flow augmentation, water supply, water-quality mitigation, navigation, recreation, and conservation of fish and wildlife. In Allegheny County, the USACE maintains eight locks and dams (fig. 1) that regulate water-surface elevations in eight navigational pools. Approximately 90 percent of the total reservoir storage is dedicated to maintaining water quality. By manipulating flows, downstream water quality is enhanced (U.S. Army Corps of Engineers, 2006). The release schedule has a profound effect on the velocity distribution and magnitude of streamflow in the Allegheny and Monongahela River systems entering Allegheny County; therefore, it is important to quantify the degree of mixing associated with sewer overflows and tributaries with receiving waters, such as the Allegheny, Monongahela, and Ohio Rivers. To assess mixing, a two-dimensional model, Resource Management Associates2 (RMA2; Donnell and others, 2011), was selected so that the longitudinal and transverse velocities could be estimated.

The Allegheny County Sanitary Authority (ALCOSAN) and the U.S. Geological Survey (USGS) collaborated to develop a two-dimensional hydrodynamic model and a water-quality model for parts of the Three Rivers in Allegheny County. The hydrodynamic model was developed to assess the effects of tributary streams, combined sewer overflows (CSOs), and sanitary-sewer overflows (SSOs) on the rivers in the vicinity of Pittsburgh, Pennsylvania. The model is capable of simulating velocity and surface-water-elevation distributions, assuming a free surface; the resulting distributions can be used to assess the fate and transport of fecal-indicator bacteria. The integrated hydrodynamic and water-quality models can be used to assess the effect of CSOs, SSOs, and other sources in the Three Rivers during both dry- and wet-weather conditions by simulating the fate and transport of fecal-indicator bacteria, and other conservative and non-conservative constituents, under open-water conditions. The results generated from the models can assist decision makers in evaluating the effects of fecal-indicator bacteria in the region.

River hydrodynamics were simulated using the numerical model RMA2; the fate and transport of selected constituents during dry- and wet-weather events can be simulated using a water-quality model such as Resource Management Associates 4 (RMA4; Letter and others, 2011). This report focuses only on the development and calibration of the hydrodynamic model, RMA2. For the purpose of calibration, the Allegheny, Monongahela, and Ohio Rivers will be treated as individual reaches on the basis of the configuration of the navigation pools, which are maintained by the USACE with a system of locks and dams. When integrated, the hydrodynamic model can computationally drive a water-quality model that can be used to assess the effect of CSOs and SSOs on receiving waters, such as the Three Rivers, by simulating the fate and transport of fecal-indicator bacteria and other conservative and non-conservative constituents during dry- and wet-weather events in the longitudinal and transverse directions.

\section{Purpose and Scope}

This report documents field activities including watersurface-elevation measurements, channel bathymetric surveys, and acoustic Doppler current profiling surveys. The report also describes the development and documents the calibration of a two-dimensional hydrodynamic model for parts of the Three Rivers in Allegheny County, Pa.

Bathymetric surveys were completed for the Allegheny, Monongahela, and Ohio Rivers beginning in late February 2006 and extending through May 2006. Channel depths were measured at 410 transects (Allegheny River, 134; Monongahela River, 158; Ohio River, 118) to establish the channel geometry. In addition, reference points in the Three Rivers region were selected or surveyed for locations to be used to establish water-surface elevation sites (tape-downs).

\section{Study Area}

The study area (fig. 1) includes parts of the Three Rivers that constitute the receiving river system where it enters and exits Allegheny County, an area of approximately 730 square miles $\left(\mathrm{mi}^{2}\right)$. It is estimated that approximately $414 \mathrm{CSOs} /$ outfalls are present within Allegheny County (National Research Council, 2005); however, the number and distribution of these structures varies from basin to basin. The city of Pittsburgh is near the center of the county, where the Allegheny and Monongahela Rivers join to form the Ohio River. Allegheny County is in a rugged section of the Allegheny Plateaus Physiographic Province, where stream erosion has created a complexly dissected area with as much as $650 \mathrm{ft}$ of relief between hilltops and valley bottoms. The tributary streams generally lie in valleys, and their topographic gradients are substantially steeper than those of the major streams; these steep gradients facilitate rapid urban runoff after precipitation events (Fulton and Buckwalter, 2004).

The model domain includes the Three Rivers and selected tributaries in Allegheny County (fig. 1). The Allegheny River reach begins with the Allegheny River Locks and Dam 3 (river mile 14.5; fig. 1) and extends downstream to Allegheny Locks and Dam 2 (river mile 6.7) and to the Point in Pittsburgh, where the confluence of the Allegheny and Monongahela Rivers form the Ohio River. Similarly, the Monongahela River reach in the model domain begins with the Monongahela Locks and Dam 3 (river mile 23.8; fig. 1) and extends beyond the Monongahela Locks and Dam 2 (river mile 11.2; fig. 1) and to the Point in Pittsburgh. The Ohio River reach extends from the Point in Pittsburgh (river mile 0.0; fig. 1) beyond the 


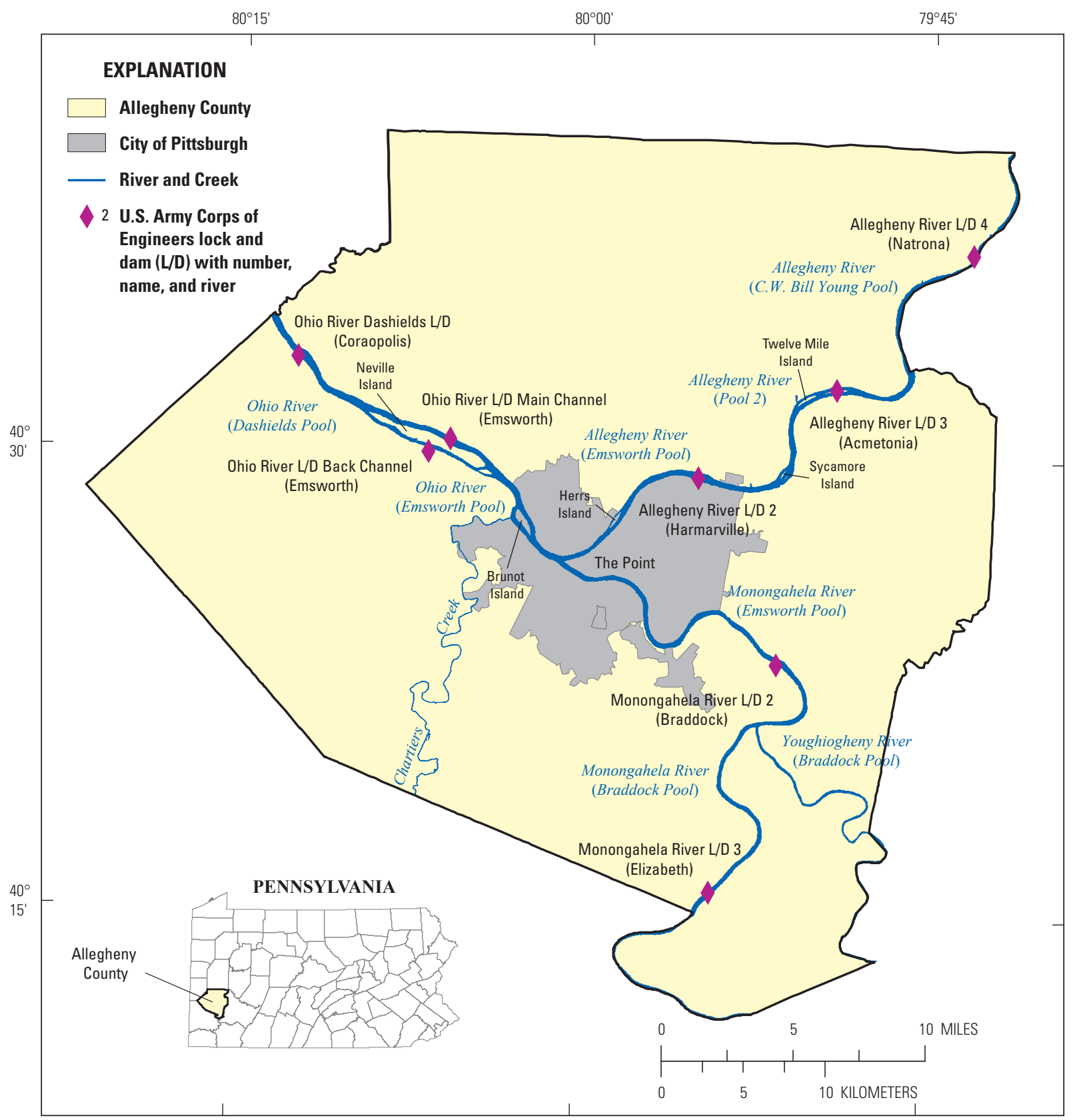

Base from U.S. geological Survey digital data, 1983, 1:100,000 Albers Equal-Area Conic projectionStandard parallels 2930 ' and $4530^{\prime} \mathrm{N}$, central meridian $7745^{\prime}$ Woo

Figure 1. Study area and locations of U.S. Army Corps of Engineers locks and dams on the Allegheny, Monongahela, and Ohio Rivers in Allegheny County, Pennsylvania. 
Ohio River Locks and Dam sites (river mile 6.2; fig. 1) on the main channel and the non-navigable back channel to the Ohio River Dashields Locks and Dam (river mile 13.3; fig. 1).

Mainstem and segments of five tributaries near their mouths (Deer Creek, Plum Creek, Squaw Run, Pine Creek, and Girtys Run) to the Allegheny River (fig. 2), five tributaries (Ninemile Run, Streets Run, Thompson Run, Turtle Creek, and Youghiogheny River) to the Monongahela River, and four tributaries (Sawmill Run, Chartiers Creek, Lowries Run, and Montour Run) to the Ohio River were incorporated into the finite-element grid. Approximately $500 \mathrm{ft}$ of each tributary upstream from the confluence with the Three Rivers was included in the model to incorporate the effects of flow contributions from each tributary. Streamflow data from USGS streamgages on the tributaries within the study area (fig. 2) were used to estimate the inflows into the Three Rivers main channels.

\section{Methods}

Reliable bathymetry and topography are paramount in developing defensible hydrodynamic models. The bathymetry, topography, and hydraulic data that were collected and used to develop the computational mesh are described in this section. Data-collection techniques used for model calibration and comparison of data (water-surface profiles, velocity distribution, and discharge) also are described.

\section{Data Collection}

Channel bathymetric data were collected from a moving boat using a NaviSound 210-kilohertz $(\mathrm{kHz})$ single-beam echosounder, ODOM 200-3 transducer, and Trimble Ag132 differentially corrected global positioning system (DGPS). The data were collected from February through May 2006. Watersurface elevations, discharge, and detailed water velocities were measured at high- and low-flow conditions in the Three Rivers study area from April 2007 through May 2008.

\section{Channel Bathymetry}

The channel bathymetry of the Three Rivers was surveyed from a moving boat at approximately one cross-section per every channel width (figs. 3-5). The surveys began in February 2006 and were completed in May 2006. Bathymetric data were collected from 118 transects on the Ohio River, 134 transects on the Allegheny River, and 158 transects on the Monongahela River. To characterize the channel bathymetry, the number and location of transects were determined by channel complexities such as geometry, alignment, and irregularities (sand bars and scour holes), and instream features such as islands, confluence points (tributary and receiving water junctions), and obstructions (bridge piers). The echosounder and DGPS were integrated into HYPACK (a navigational software package) to collect geo-referenced bathymetric data at predefined cross sections for each reach. Differential corrections were provided by a commercially available service (OmniStar). The echosounder is specified by the manufacturer to have an accuracy of 1 centimeter $(\mathrm{cm})$ at one standard deviation. The DGPS unit is specified by the manufacturer to be accurate to $3.3 \mathrm{ft}$ at two standard deviations; tests and prior use of this unit indicate that typically about 80 percent of the data are within $3.3 \mathrm{ft}$ of the true location.

Raw bathymetric data were collected and processed to filter (1) problems related to the echosounder processing of multiple-return acoustic signals in shallow water (which causes the measured depth to be twice the actual depth), (2) DGPS problems associated with multi-pathing errors and constellation coverages, and (3) redundant areas along the banks caused by failure to properly end data collection at various cross sections. Analog printouts of the bottom profiles were produced as part of the data-collection process and used as a qualityassurance measure because multiple-return errors can easily be identified in the analog printouts. The processed bathymetric data (including edge of water points) were exported to a text file that included geographic coordinates and a corresponding depth for each of the surveyed data points. The water depths were then subtracted from the water-surface elevations referenced to North American Vertical Datum of 1988 (NAVD 88) to establish an elevation for the streambed, which was interpolated to generate the bathymetry of the hydrodynamic model. These elevations were then used to construct the model mesh required by RMA2 model. In general, the surveys indicate a fairly uniform channel in all three rivers with the exception of areas where the navigation channel was dredged or in areas near bridge piers and confluences of tributaries where scour and deposition were observed. Depths varied depending on (1) the pool being surveyed and (2) the timing of the surveys (low versus high streamflow). Depths ranged from near zero to 42.4 feet with a median depth of 16.1 feet.

\section{Water-Surface Elevations}

Water-surface elevations were established using measured water levels at USGS streamgages on the Three Rivers and at USACE locks and dams. To document changes in river stage during each survey, water-surface elevations from hourly recorded USACE stage data were used for the upper and lower end of each navigational pool. An average water-surface slope (hydraulic grade) was computed using the stage and chainage (center line distance from two USACE locks and dams that regulate a given pool). Based on the stage reported for a particular time stamp (clock time when the bathymetric data were collected), a water-surface elevation at a given transect was computed using routines in HYPACK. In addition, water-surface-elevation sites (tape-downs) selected from surveyed reference marks at selected CSO outfalls along the Three Rivers near the mid-points of the pools were used to supplement the streamgage station water-surface elevations at the upstream and downstream ends of the pools and at USGS streamgage 03085152 (fig. 2) at the Point State Park in Pittsburgh. 


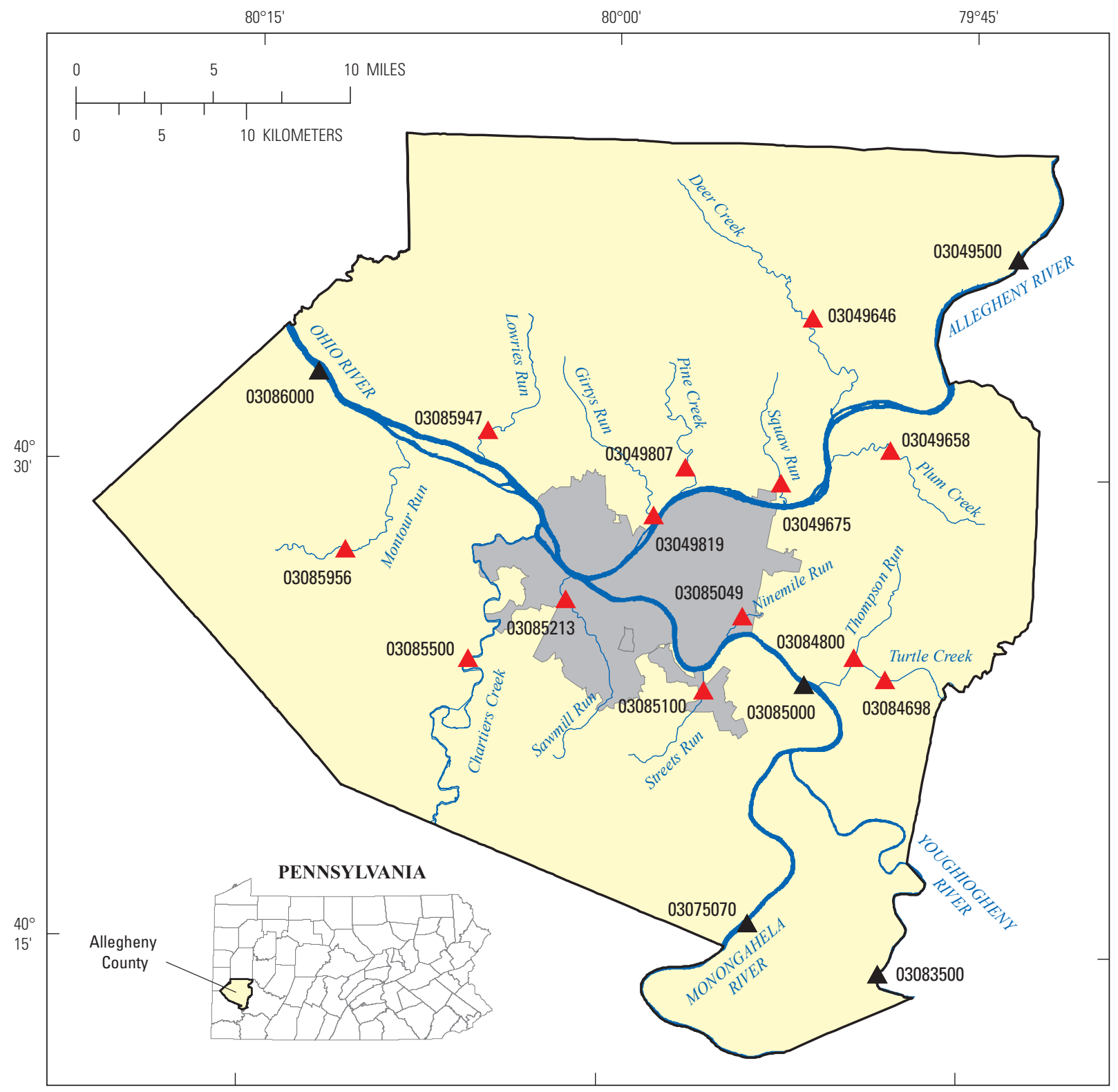

Base from U.S. geological Survey digital data, 1983, 1:100,000 Albers Equal-Area Conic projectionStandard parallels $2930 \mathrm{~N}$ and $4530^{\prime} \mathrm{N}$, central meridian $7745^{\prime} \mathrm{W}_{00}$

\section{EXPLANATION}

\section{U.S. Geological Survey streamgage-station number and name}

03049500 Allegheny River at Natrona, PA 03049646 Deer Creek near Dorseyville, PA 03049658 Plum Creek at Milltown, PA 03049675 Squaw Run near Fox Chapel, PA 03049807 Pine Creek at Grant Avenue at Etna, PA 03049819 Girtys Run above Grant Avenue at Millvale, PA 03075070 Monongahela River at Elizabeth, PA 03083500 Youghiogheny River at Sutersville, PA 03084698 Turtle Creek at Wilmerding, PA
03084800 Thompson Run at Turtle Creek, PA 03085000 Monongahela River at Braddock, PA 03085049 Ninemile Run near Swissvale, PA 03085100 Streets Run at Hays, PA 03085213 Sawmill Run at Duquesne Heights near Pittsburgh, PA 03085500 Chartiers Creek at Carnegie, PA 03085947 Lowries Run at Camp Horne near Emsworth, PA 03085956 Montour Run at Scott Station near Imperial, PA 03086000 Ohio River at Sewickley, PA
Allegheny County

City of Pittsburgh

Rivers and selected tributaries

U.S. Geological Survey streamgage-station

$\triangle$ Mainstem

A Tributary

Figure 2. Location of U.S. Geological Survey streamgages in Allegheny County, Pennsylvania. 


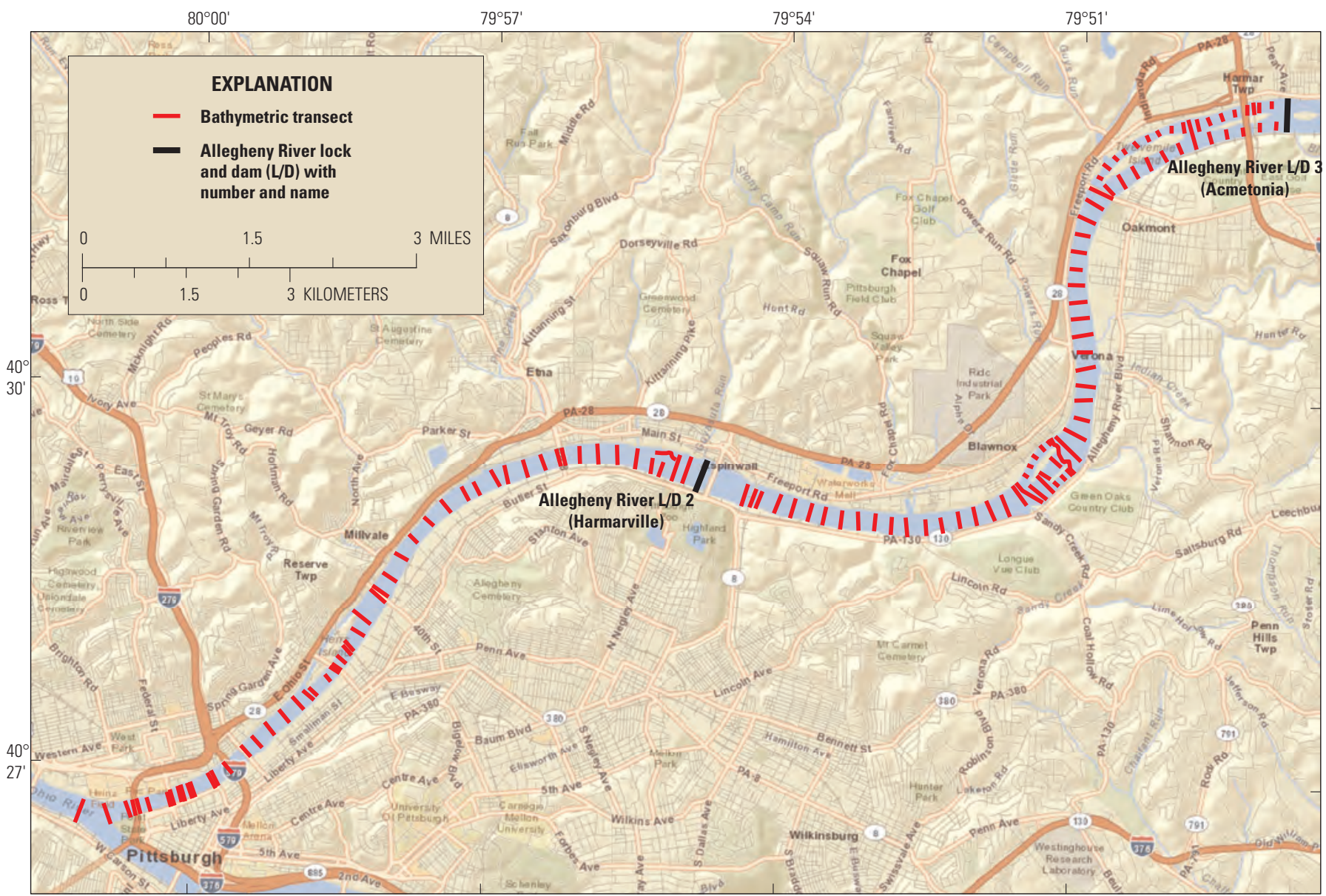

Base from ESRI, World Street Map, 2012

NAD 1983, State Plane Pennsylvania South

Figure 3. Location of bathymetric transects and locks and dams on the Allegheny River in Allegheny County, Pennsylvania. 


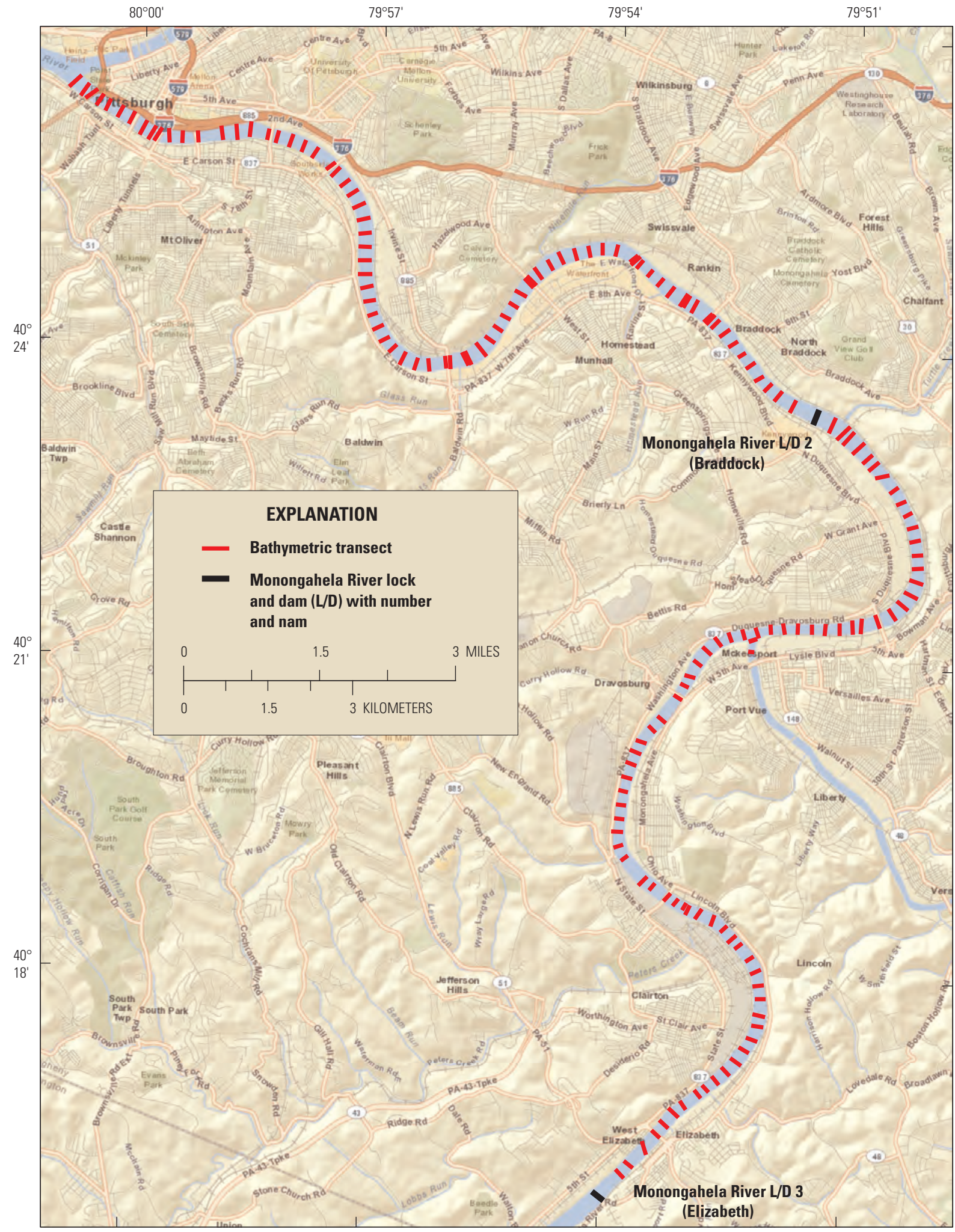

Base from ESRI, World Street Map, 2012

NAD 1983, State Plane Pennsylvania South

Figure 4. Location of bathymetric transects and locks and dams on Monongahela River in Allegheny County, Pennsylvania. 


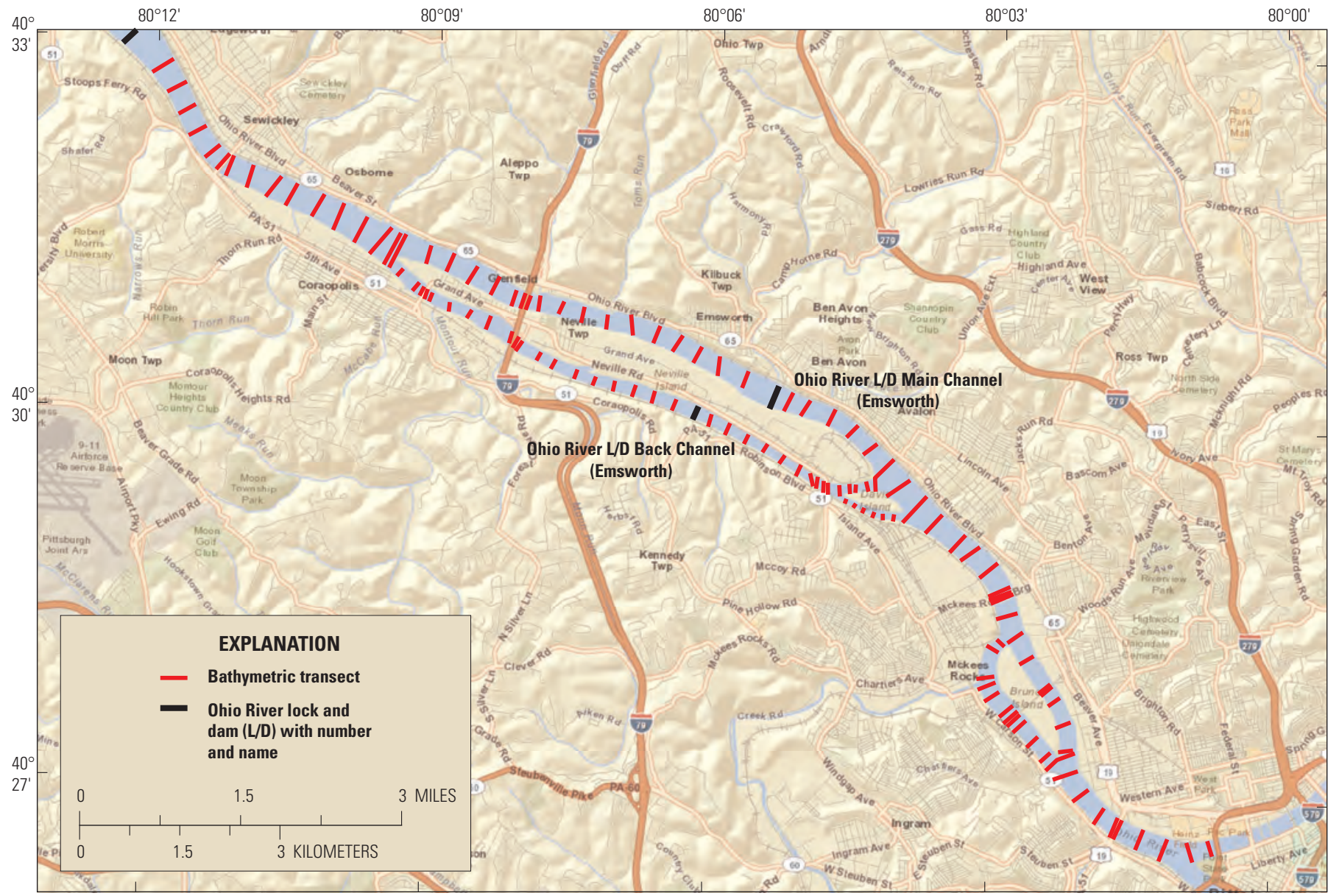

Base from ESRI, World Street Map, 2012

NAD 1983, State Plane Pennsylvania South

Figure 5. Location of bathymetric transects and locks and dams on Ohio River in Allegheny County, Pennsylvania. 


\section{Velocity and Discharge}

Velocity and streamflow data were collected using a boat-mounted Acoustic Doppler Current Profiler (ADCP) at selected cross sections in each river reach (figs. 6-11). The position of the boat and navigation points were established using a DGPS, which received differential corrections from the OmniStar commercial satellite. Advances in velocitymeasurement technology allow three-dimensional velocities to be measured from a moving boat by using an ADCP (Mueller and Wagner, 2009). All velocities were measured with an RD Instruments $600 \mathrm{kHz}$ Rio Grande ${ }^{\mathrm{TM}} \mathrm{ADCP}$. Three-dimensional velocities were measured from approximately $2.0 \mathrm{ft}$ beneath the water surface to within 6 percent of the depth of channel bottom. Depth averaged velocities were computed from the three-dimensional measured data at each cross section. These discrete depth-averaged velocities were computed as an average of the measured velocity; no velocities were computed for the unmeasured parts of the water column.

Discharge was measured by the ADCP for each velocityprofile section. Established methods were used to estimate the discharge in the unmeasured top and bottom parts of the profile (Simpson and Oltmann, 1991). A separate discharge measurement was made during the surveys at a location that met USGS site-selection protocols for making discharge measurements (Turnipseed and Sauer, 2010). To compensate for the unsteady variations in streamflow associated with lockages, reservoir releases, and hydropower releases during the surveys, discharge and water-surface elevation measurements made at the beginning and end of velocity data collection were averaged to produce a time-averaged flow rate and watersurface profile that were representative of the survey period. However, in some instances the variability of discharge in a reach during a velocity survey was substantial, and the data could not be used for model calibration.

\section{Hydrodynamic Modeling}

A two-dimensional hydrodynamic model of the Three Rivers study area was developed using the field data described previously and color aerial photography, which was georeferenced and used to assist with mesh construction. The entire model domain is 52.5 miles long ( 12.9 miles of the Ohio River, 15.9 miles of the Allegheny River and 23.7 miles of the Monongahela River), consisting of four separate and independent segments that represent the four navigational pools in the study area (Allegheny Pool 2, Braddock Pool, Emsworth Pool, and Dashields Pool; fig. 1). The lateral extent of the model coincides approximately with bank-full conditions; floodplains are generally small, given the relatively steep topography of the area, and were not included in the model because the emphasis of model application will be on periods spanning the recreational season and within bankfull flows.

RMA2 is a two-dimensional depth-averaged, finiteelement hydrodynamic numerical model capable of computing water-surface elevations and horizontal-velocity components for sub-critical, free-surface flow in two-dimensional flow fields (Donnell and others, 2011). The model is designed for situations where vertical accelerations are negligible and velocity vectors generally point in the same direction over the entire depth of the water column at any discrete moment in time. The model is not intended for applications in which vortexes, vibrations, or vertical accelerations are the primary interests (Donnell and others, 2011). Typical applications of the RMA2 numerical model include calculating water-surface elevations and flow distribution around islands; flow patterns at bridges with one or more relief openings, in contracting and expanding reaches, into and out of off-channel hydropower plants, and river junctions; circulation and transport in water bodies with wetlands; and general water levels and flow patterns in rivers, reservoirs, and estuaries. The modeling interface Surface Water Modeling System (SMS) (version 10.1) developed by Aquaveo (2012) was used in the study.

\section{Computational Grid}

Two separate finite-element meshes for the Three Rivers study area were developed. Initially, a refined mesh was generated in an attempt to calibrate hydraulic parameters on the basis of measured velocity and water-surface elevation. The refined mesh used by ALCOSAN to simulate water quality produced run times that were too long to be used as a management tool; therefore, a coarser mesh was created for the hydrodynamic model consisting of approximately 10 percent of the number of grid cells (elements) used to build the refined mesh. The coarse-mesh model was used to calibrate the field measurements. Although the refined mesh better represented the velocity distribution along the banks and at the upstream and downstream tips of the islands, the overall differences between the two mesh configurations were minor, and the computational efficiencies gained using the coarse mesh outweighed the minor and localized improvements provided by the refined mesh. From this point on in the report, all discussions of model development and calibration will be of the coarse-mesh configuration.

The final finite-element mesh for the four separate segments of the hydrodynamic model consists of elements ranging in size from a maximum of approximately 106,000 square feet $\left(\mathrm{ft}^{2}\right)$ in the main channel to approximately $2,500 \mathrm{ft}^{2}$ along the banks at tributary confluences. An example of the computation mesh configuration is presented in figure 12. Each element within the computational mesh was assigned a material type, which is associated with a unique set of hydraulic characteristics (Manning's $n$ roughness, eddy viscosity, marsh porosity) that directly affects the manner in which water moves through an element. The actual hydraulic characteristics associated with each material type were initially assigned on the basis of published guidance (Chow, 1988; Wagner and Mueller, 2001; Wagner and Mueller, 2002) and engineering judgment and were adjusted during the calibration process to match measured velocities and stage at actual transects for two flow events (low and high streamflow). The final Manning's 


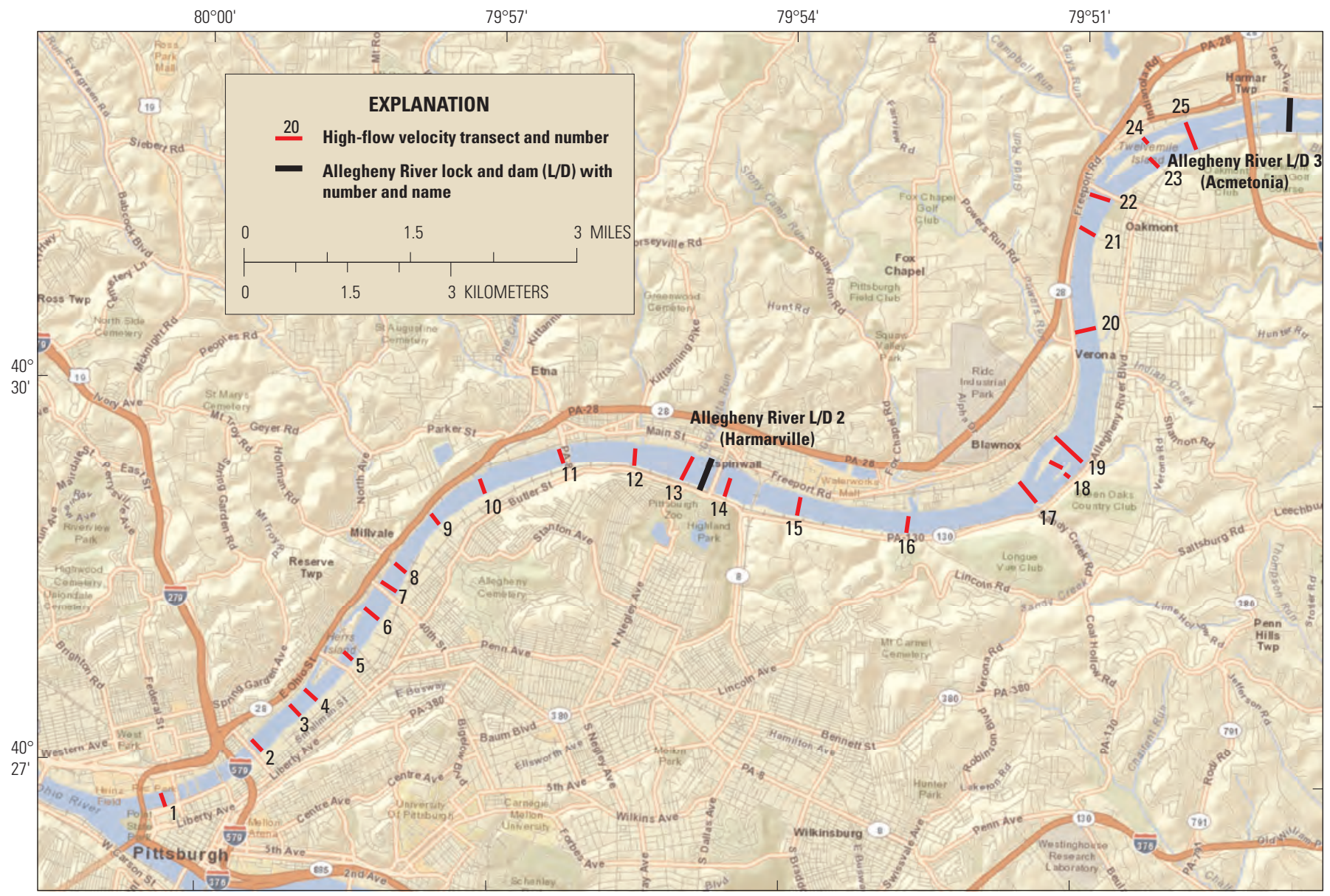

Base from ESRI, World Street Map, 2012

NAD 1983, State Plane Pennsylvania South

Figure 6. Location of high-flow velocity transects and locks and dams on the Allegheny River in Allegheny County, Pennsylvania.

$n$ roughness values ranged from 0.026 in the main channel to 0.031 for a single row of elements along the banks. Eddy viscosity was allowed to vary from element to element on the basis of the unique element size and calculated velocity using the Peclet number approach presented in equation 1 (Donnell and others, 2011).

where

$$
P=\frac{\rho u d x}{E}
$$

$$
\begin{array}{ll}
P & \text { is Peclet number; } \\
\rho & \text { is fluid density, } 1.94 \text { slugs per cubic foot }\left(\mathrm{ft}^{3}\right) \\
u & \text { is average element velocity, in feet per } \\
& \text { second ( } \mathrm{ft} / \mathrm{s}) \text {; }
\end{array}
$$

The Peclet number controls the relation between the average element velocity magnitude, the element length, fluid density and eddy viscosity (Donnell and others, 2011). The final Peclet number that was used in the model was 18 , which is within the published range of recommended values (Donnell and others, 2011).

\section{Boundary Conditions}

The steady-state inflow boundary conditions for all four of the model segments were established from the average of the discharge measurements made before and after the velocity surveys. A summary of the inflow boundary conditions for the calibration of each model segment is presented in table 1 and a summary of flow statistics for four USGS continuous-record streamgages in the Three Rivers study area is presented in table 2. A summary of the locks and dam characteristics in the study area is presented in table 3 . On the basis of the calibration and validation results that included water-surface elevations and velocities, the model is a representative simulation of the Three Rivers flow patterns for discharges ranging from 4,050 to 47,400 cubic feet per second $\left(\mathrm{ft}^{3} / \mathrm{s}\right)$ on the Allegheny River; 2,550 to $40,000 \mathrm{ft}^{3} / \mathrm{s}$ on the Monongahela River; and 10,900 to $99,000 \mathrm{ft}^{3} / \mathrm{s}$ on the Ohio River. 


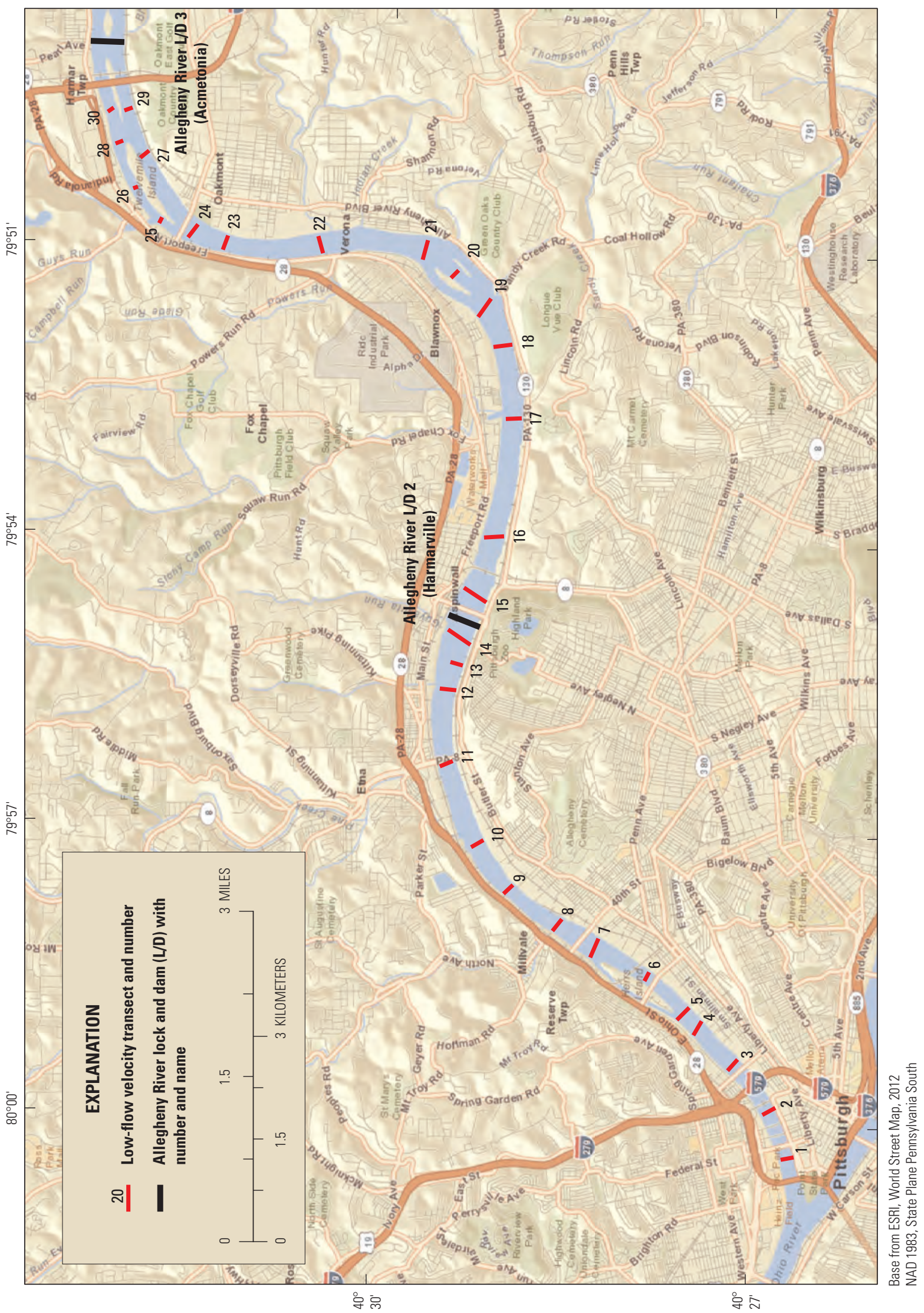

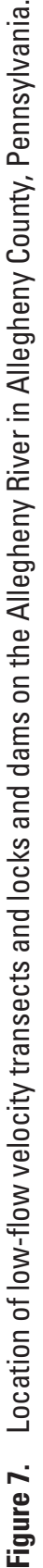




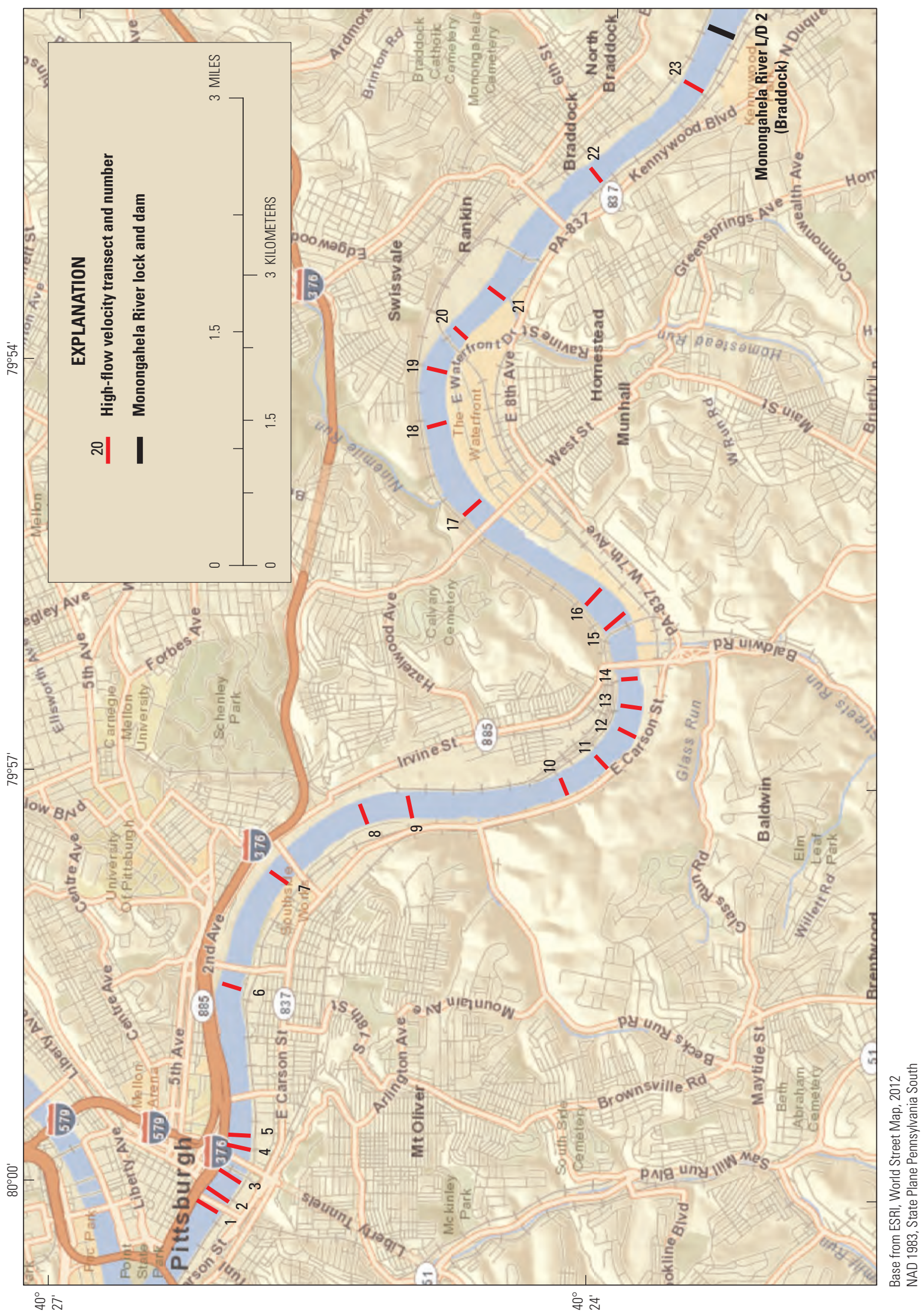

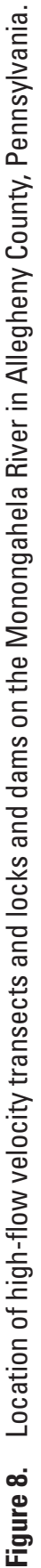




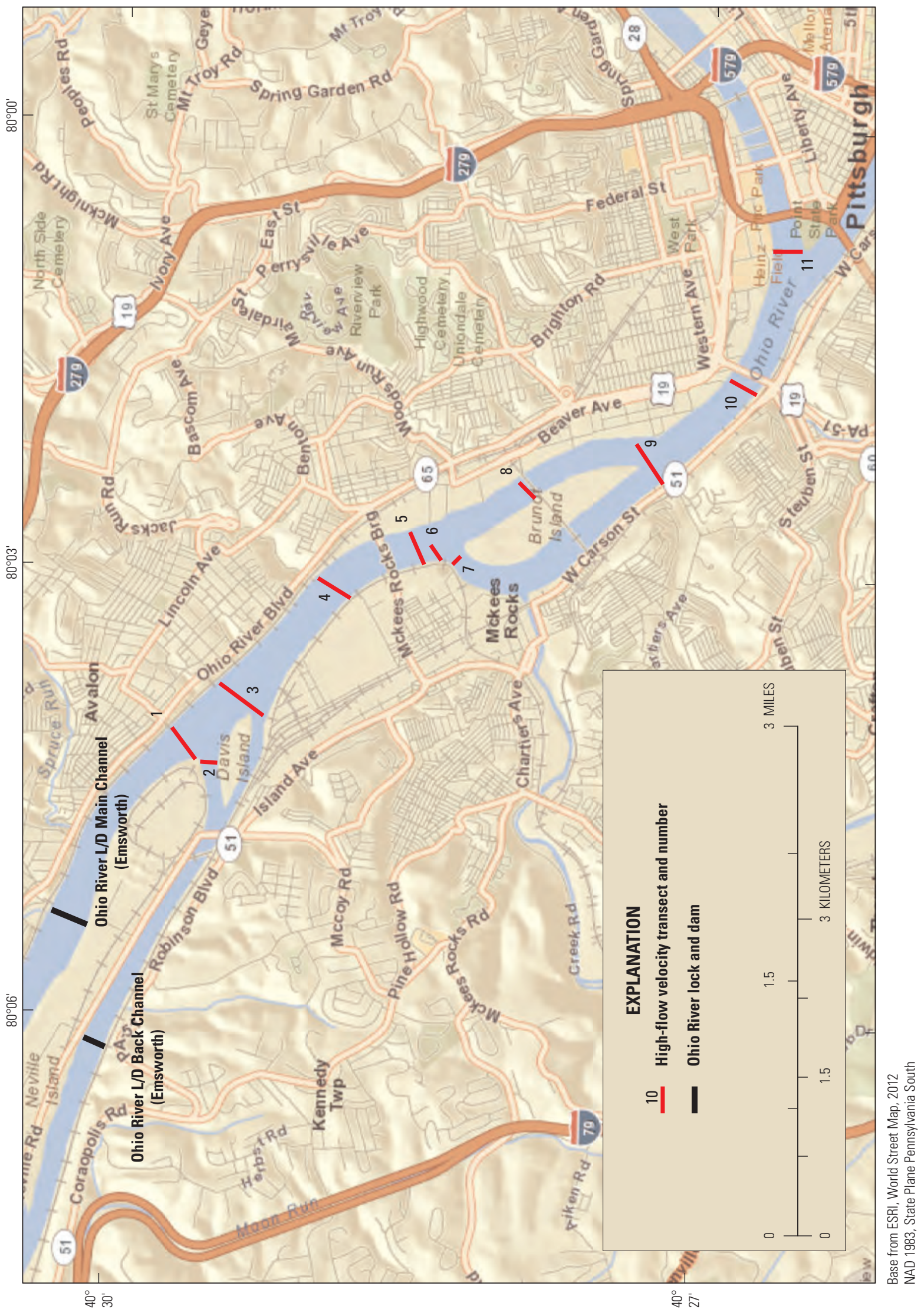

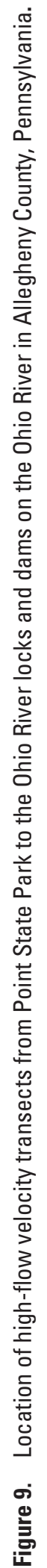




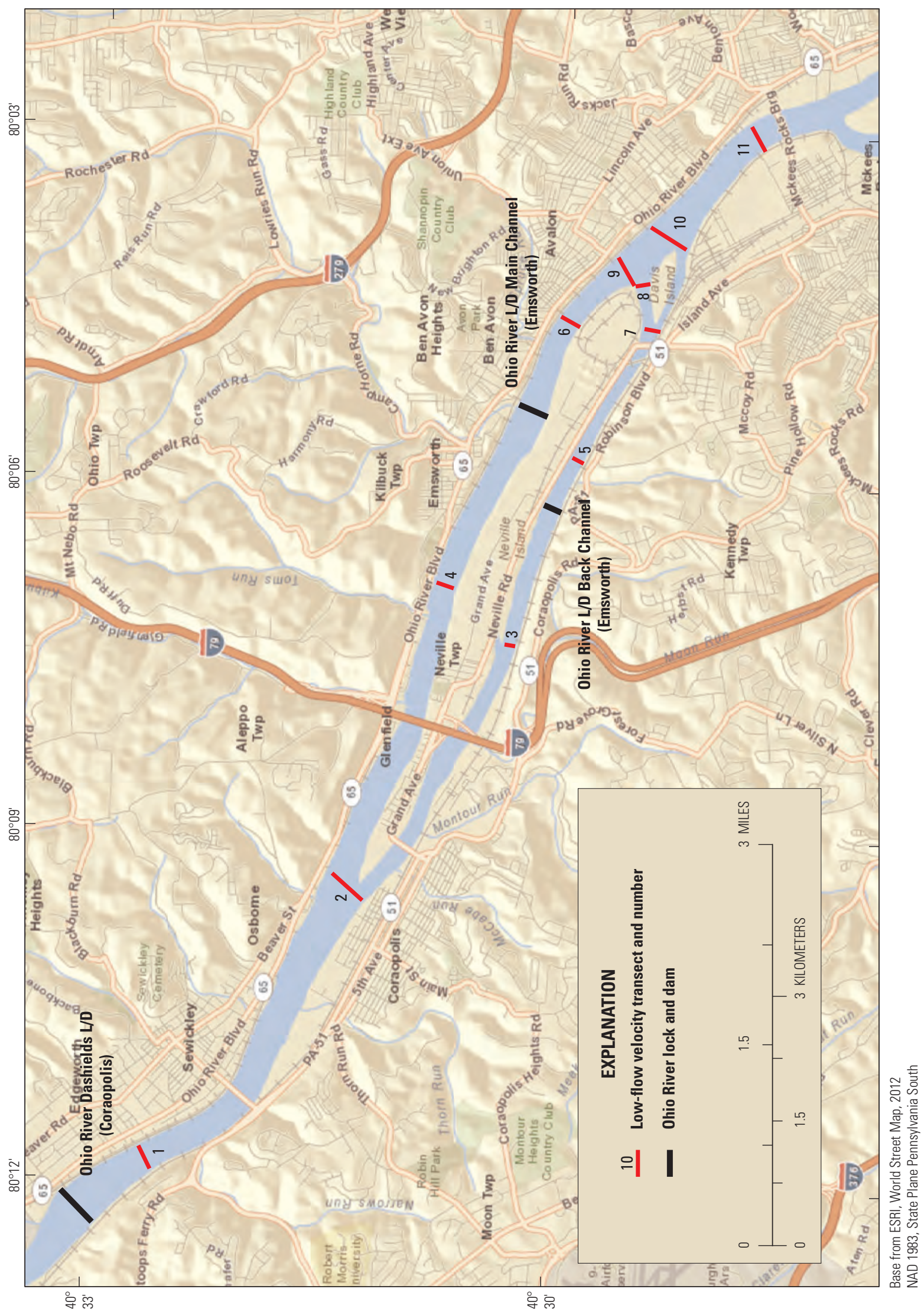




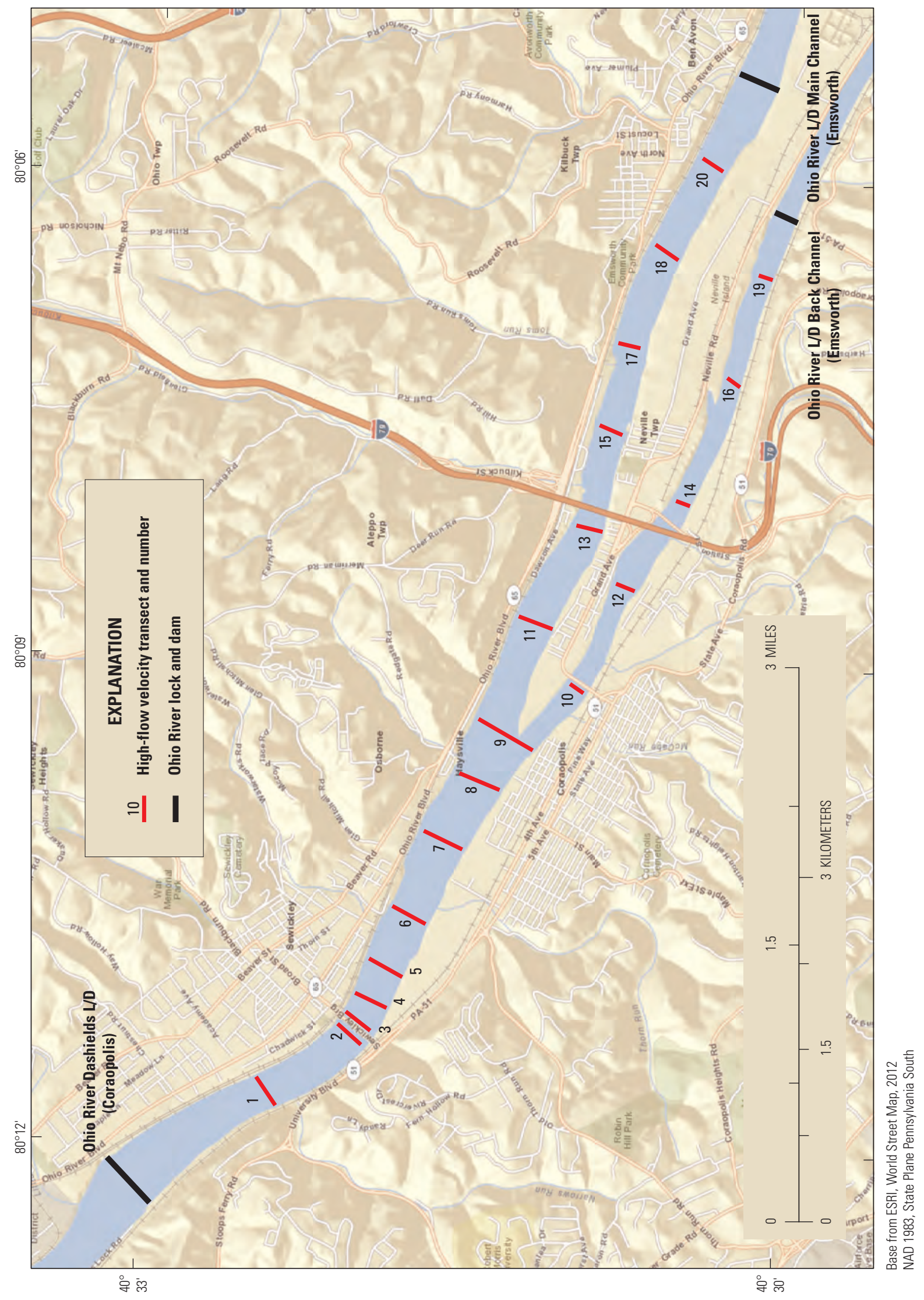




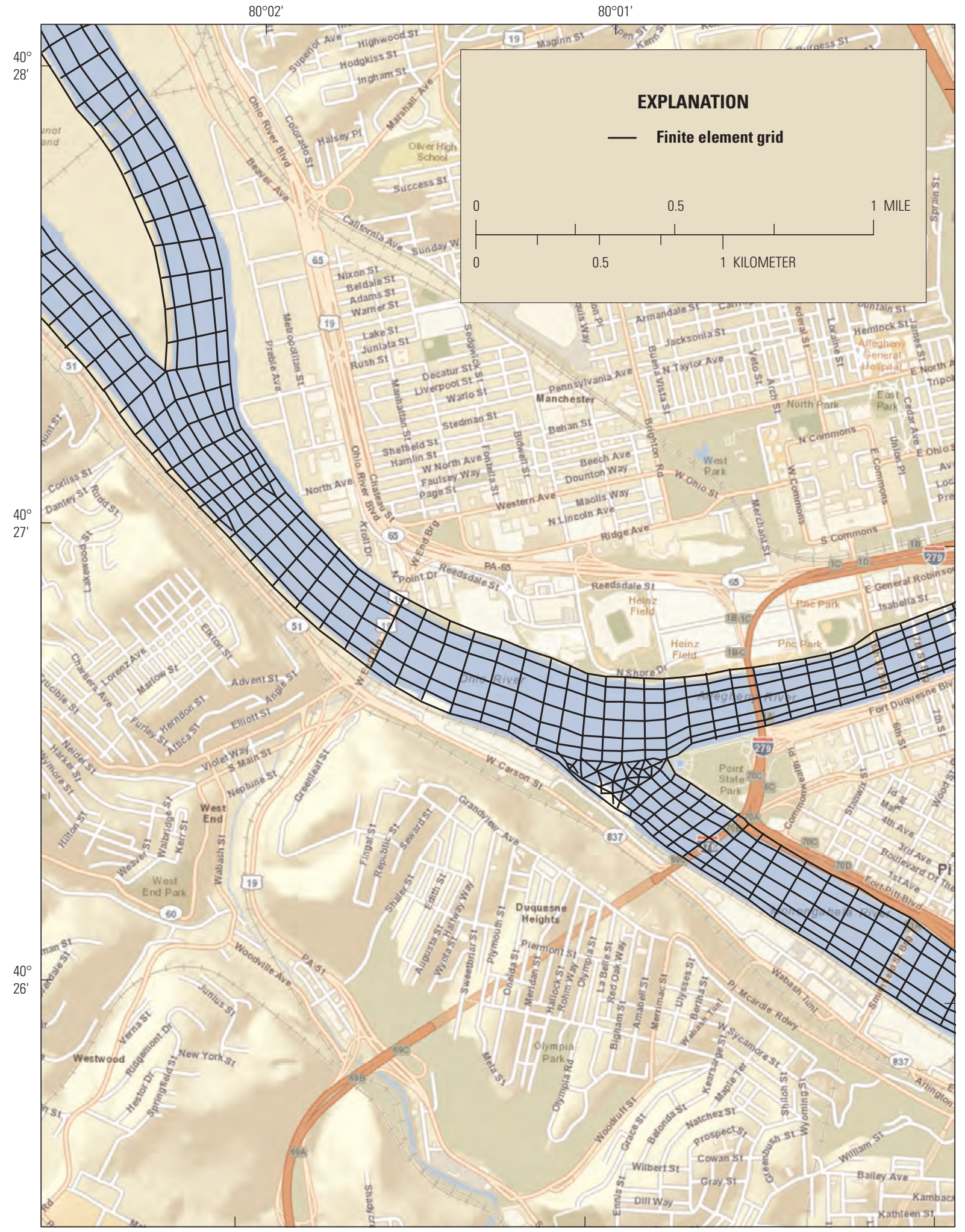

Base from ESRI, World Street Map, 2012 NAD 1983, State Plane Pennsylvania South

Figure 12. Example of the finite-element grid configuration for the hydrodynamic model of the Allegheny, Monongahela, and Ohio Rivers in Allegheny County, Pennsylvania. 


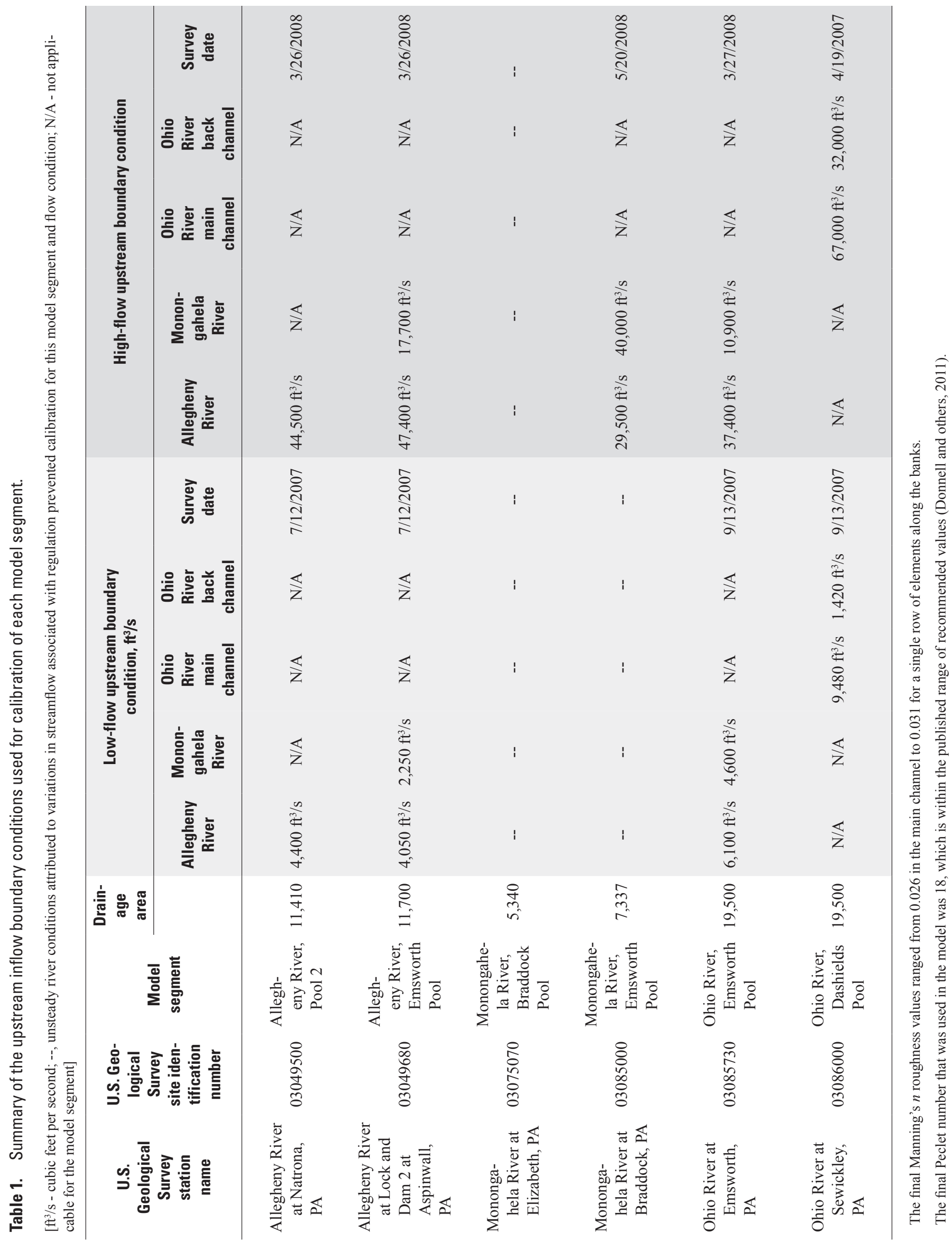


Table 2. Summary of streamflow statistics at four U.S. Geological Survey continuous-record streamgaging stations' ${ }^{1}$, October 1, 1968 to September 30, 2004, in the Allegheny, Monongahela, and Ohio Rivers in Allegheny County, Pennsylvania.

$\left[\mathrm{ft}^{3} / \mathrm{s}\right.$, cubic feet per second]

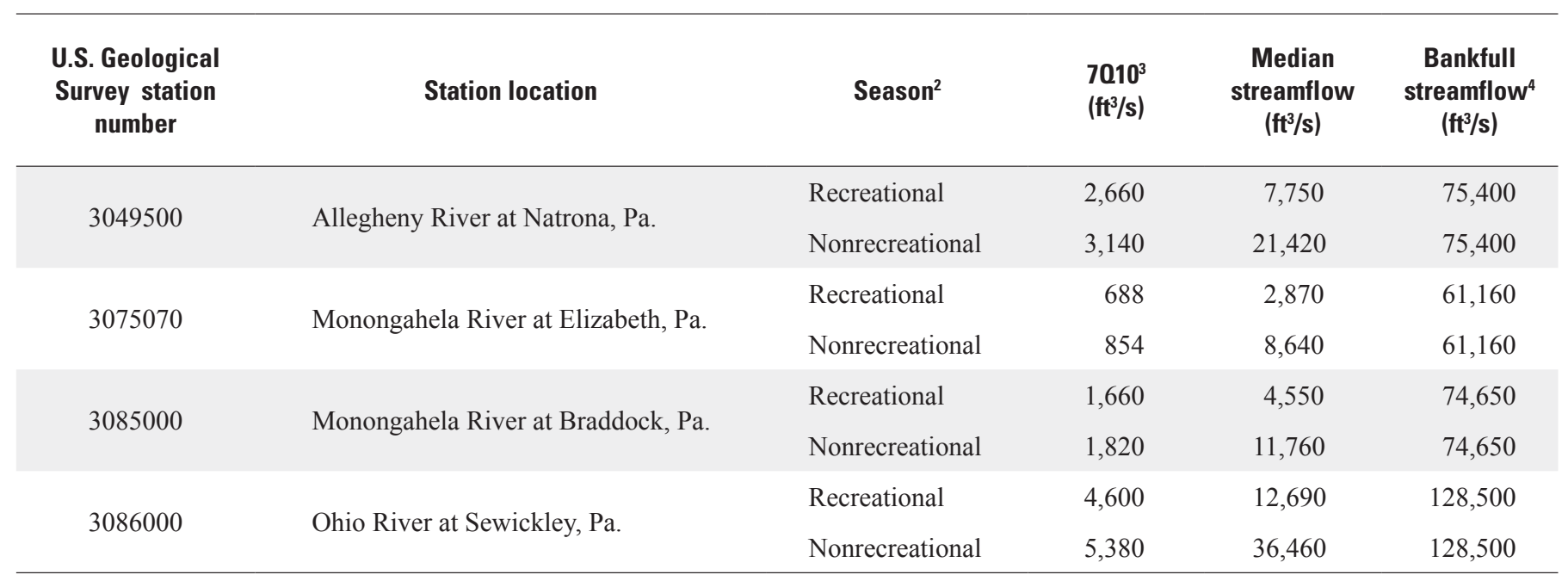

${ }^{1}$ U.S. Geological Survey, 2012.

${ }^{2}$ The recreational season extends from May 15 through October 1; the nonrecreational season comprises the remainder of the year.

${ }^{3}$ The 7 Q10 streamflow refers to the minimum 7-day flow period that occurs every 10 years; it is typically a low-flow design metric.

${ }^{4}$ Bankfull streamflow refers to the 0.80 exceedance probability annual peak flow, which is approximately equal to the 1.25 -year recurrence interval. 


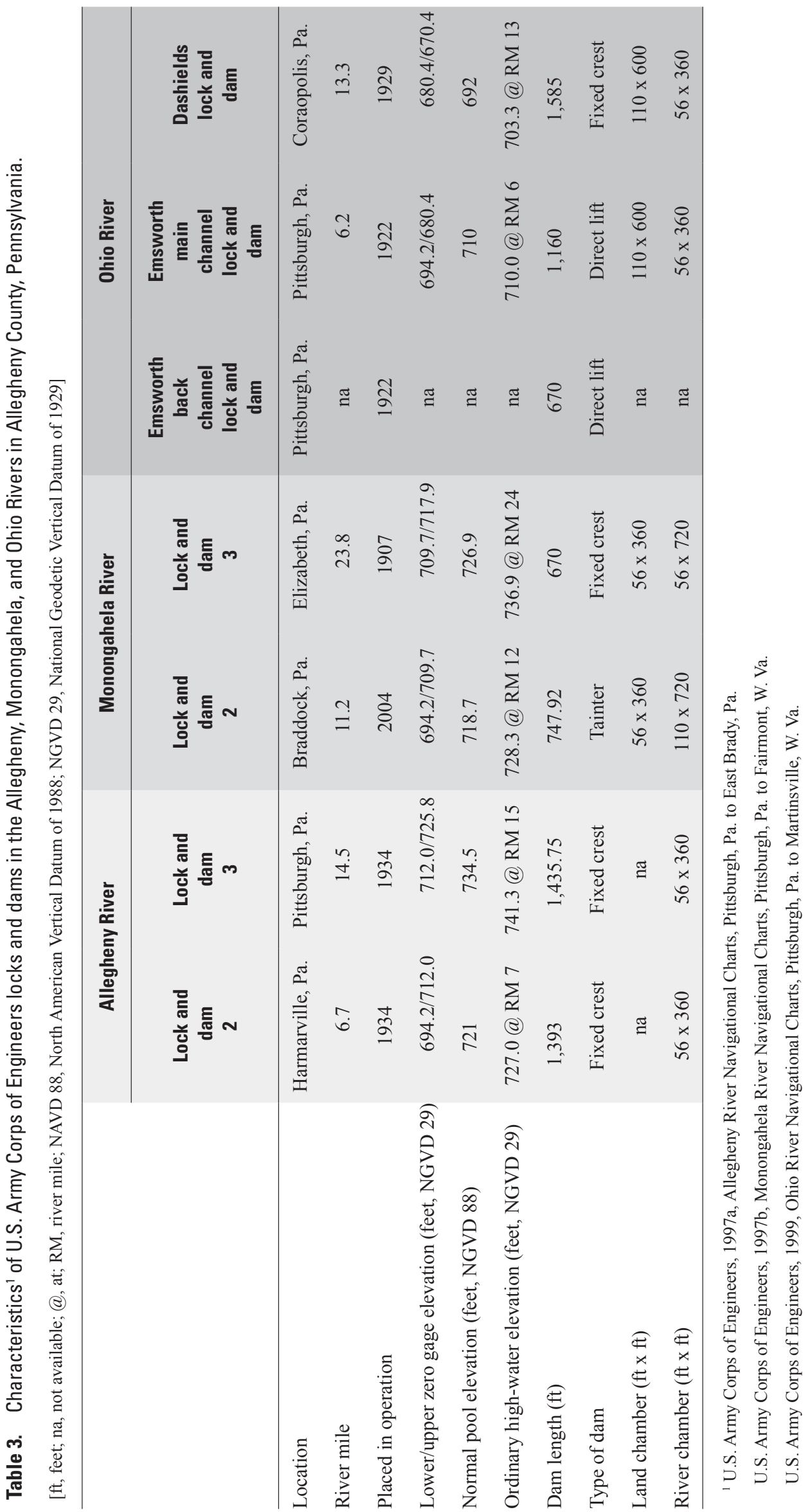


The inflow distribution across the upstream boundaries for all model segments was based on depth. The downstream boundary conditions for all model segments were assigned water-surface elevations, except for the Emsworth back-channel boundary (fig. 1), where a flow boundary was prescribed to represent the distribution of streamflow released through the Emsworth locks and dam gates. The downstream model boundaries for each model segment coincided with a USGS streamgage, and the corresponding water-surface elevation was determined from averaging the water-level data over the duration of the ADCP surveys. The downstream flow boundary condition for the Emsworth back channel was determined from ADCP discharge measurements in the back channel during the ADCP surveys.

\section{Hydrodynamic Model Calibration}

Water-surface elevations and velocity distributions in the individual model segments were compared to measured data to evaluate the ability of each model segment to represent field conditions. The roughness values and eddy viscosity terms were adjusted until the simulated water-surface elevations, velocities, and flow continuity around islands high-flow conditions matched those measured in the field. The low-flow condition was simulated without changing the computational mesh or model parameters, and the simulated water-surface elevations, velocities, and flow continuity around islands were compared with those measured in the field. Minor adjustments to the element material zones and properties were made to optimize the calibration for both flow conditions. Flow continuity was checked throughout the models to assure that (1) mass was being conserved, which is critical for successful application of the coupled water-quality model and (2) flow was being accurately distributed around islands in the main channel. A tolerance of $+/-3$ percent in mass conservation discrepancy is typically acceptable for most hydrodynamic models (Donnell and others, 2011). A summary of the calibration results for each model segment is presented below.

\section{Allegheny River, Pool 2 Calibration Results}

The summary of the water-surface elevation calibration results for Allegheny River Pool 2 is presented in table 4. Mass was conserved throughout the domain of the Allegheny River Pool 2 model segment to within 0.6 percent for both flow conditions, and the model provided good agreement with measured flow splits around the three islands (table 5). The larger continuity differences observed for high-flow conditions through the middle channel at Nine-Mile and Sycamore Islands is related to the fact that there was a difference of $1,850 \mathrm{ft}^{3} / \mathrm{s}$ between the simulated discharge (representing the mean discharge over the data-collection period) and the measured instantaneous total flow in the river just prior to the measurement between the islands. The model-calibration process also included a comparison of measured and simulated cross-sectional velocity profiles at 13 cross sections in the Pool 2 model segment. A comparison of the simulated- and measured-velocity profiles for high-flow conditions at crosssection 17 (fig. 6) and low-flow conditions at cross-section 19 (fig. 7), which are directly downstream from Sycamore and Nine-Mile Islands, is illustrated in figure 13. Aside from the cross sections measured in the vicinity of tributaries, which had local areas of dynamic bathymetry that were not represented in the model, the shape of the measured- and simulatedvelocity distributions compared well. A comparison of the velocity magnitudes and directions for high-flow conditions at cross-section 17 is presented in figure 14. A statistical summary of the differences in measured and simulated velocities is presented in table 6 .

\section{Emsworth Pool Calibration Results}

Within the Emsworth Pool, three separate calibrations results were conducted, one for each river reach in the pool (Allegheny River, Monongahela River, and Ohio River). The calibration for each river reach within the Emsworth Pool model segment will be presented individually.

\section{Allegheny River}

The summary of the water-surface elevation calibration results for the Allegheny River reach of the Emsworth Pool is presented in table 7. Mass was conserved throughout the domain of the Allegheny River, Emsworth pool model segment, to within 0.3 percent for high- and low-flow conditions and provided good agreement with the measured flow split around Herrs Island (table 8). The model-calibration process consisted of comparing measured and simulated crosssectional velocity profiles at 13 cross sections for high-flow conditions and 17 cross sections for low-flow conditions in the Allegheny reach of the Emsworth Pool model segment (figs. 6-10). Comparisons of the simulated- and measuredvelocity profiles for high-flow conditions at cross-section 4 (fig. 6) and low-flow conditions at cross-section 5 (fig. 7), which are directly downstream from Herrs Island are illustrated in figure 15. A comparison of the velocity magnitudes and directions for high-flow conditions at cross-section 4 is presented in figure 16. The shape of the measured- and simulated-velocity distributions compared well except in areas where the bathymetry could not be defined, such as the right bank downstream from Herrs Island where boat access and the echosounder-depth restrictions limited data collection. A statistical summary of the differences in measured and simulated velocity results is presented in table 9. 
Table 4. Summary of water-surface elevation calibration results for the Allegheny River, Pool 2 model segment, in Allegheny County, Pennsylvania.

[NAVD, North American Vertical Datum of 1988]

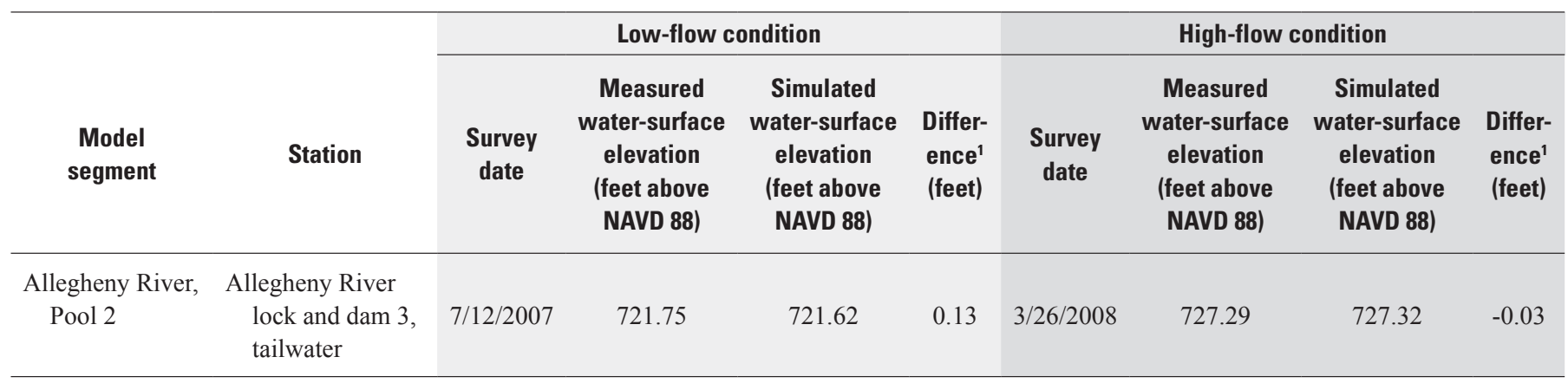

${ }^{1}$ Differences are determined by subtracting measured from simulated water-surface elevations.

\section{Monongahela River}

Despite multiple attempts, field personnel were unable to collect a steady-state low-flow calibration dataset for the Monongahela River Emsworth Pool segment. Upstream reservoir releases and lockages from Braddock lock and dam caused flow to vary in excess of 100 percent during the low-

Table 5. Summary of flow-split calibration results for islands in the Allegheny River, Pool 2 model segment, in Allegheny County, Pennsylvania.

[Left and right are in the downstream direction; $\mathrm{ft}^{3} / \mathrm{s}$, cubic feet per second; -- , no data collected]

\begin{tabular}{|c|c|c|c|c|}
\hline \multirow[b]{2}{*}{ Location } & \multicolumn{2}{|c|}{ Low-flow condition } & \multicolumn{2}{|c|}{ High-flow condition } \\
\hline & $\begin{array}{c}\text { Measured } \\
\text { flow } \\
\left(\mathrm{ft}^{3} / \mathrm{s}\right)\end{array}$ & $\begin{array}{c}\text { Simulated } \\
\text { flow } \\
\left(\mathrm{ft}^{3} / \mathrm{s}\right)\end{array}$ & $\begin{array}{c}\text { Measured } \\
\text { flow } \\
\left(\mathrm{ft}^{3} / \mathrm{s}\right)\end{array}$ & $\begin{array}{c}\text { Simulated } \\
\text { flow } \\
\left(\mathrm{ft}^{3} / \mathrm{s}\right)\end{array}$ \\
\hline $\begin{array}{l}\text { 12-mile } \\
\text { Island, right } \\
\text { channel }\end{array}$ & -- & -- & 12,700 & 13,000 \\
\hline $\begin{array}{l}\text { 12-mile } \\
\text { Island, left } \\
\text { channel }\end{array}$ & -- & -- & 31,900 & 31,100 \\
\hline $\begin{array}{l}\text { Sycamore } \\
\text { Island, right } \\
\text { channel }\end{array}$ & -- & -- & -- & 7,700 \\
\hline $\begin{array}{l}\text { Nine-Mile and } \\
\text { Sycamore } \\
\text { Islands, middle } \\
\text { channel }\end{array}$ & 1,900 & 2,200 & $23,000 *$ & 21,100 \\
\hline $\begin{array}{l}\text { Nine-Mile } \\
\text { Island, left } \\
\text { channel }\end{array}$ & -- & -- & 15,500 & 15,300 \\
\hline
\end{tabular}

* Simulated flow is $1,850 \mathrm{ft}^{3} / \mathrm{s}$ less than the instantaneous measured flow in the river just prior to the measurement of the middle channel. flow surveys on the Monongahela River. The summary of the water-surface-elevation calibration for the Monongahela River reach of the Emsworth Pool for high-flow conditions is presented in table 7. Mass was conserved throughout the domain of the Monongahela River reach of the Emsworth Pool model segment to within 0.2 percent for high-flow conditions. It should be noted that there are no islands in this reach; therefore, an analysis of flow conservation related to flow splits was not necessary. The model calibration process consisted of comparing measured and simulated cross-sectional velocity profiles at 23 cross sections for high-flow conditions in the Monongahela River reach of the Emsworth Pool model segment (fig. 8). A comparison of the simulated- and measured-velocity profiles for cross-sections 7 and 19 is shown in figure 17 and figure 18, respectively. The distribution of velocity magnitudes and directions for the high-flow event in the vicinity of cross-section 19 is presented in figure 19. Aside from the cross sections measured in the vicinity of tributaries, which had local areas of changing bathymetry that were not represented in the model, the shape of the measured- and simulated-velocity distributions compared well. A statistical summary of the differences in measured- and simulated-velocity calibration results is presented in table 9 .

\section{Ohio River}

The summary of the water-surface-elevation calibration results for the Ohio River reach of the Emsworth Pool is presented in table 7. Mass was conserved throughout the domain of the Ohio River reach of the Emsworth Pool model segment to within 0.8 percent for high- and low-flow conditions, and the model provided excellent agreement with measured flow splits around Brunot Island but poorer agreement around Neville and Davis Islands (table 10). The larger continuity differences observed for high-flow conditions in the main channel side of Neville Island are related to unsteady flows experienced during the surveys, which resulted in a difference of approximately $2,700 \mathrm{ft}^{3} / \mathrm{s}$ between the total simulated 

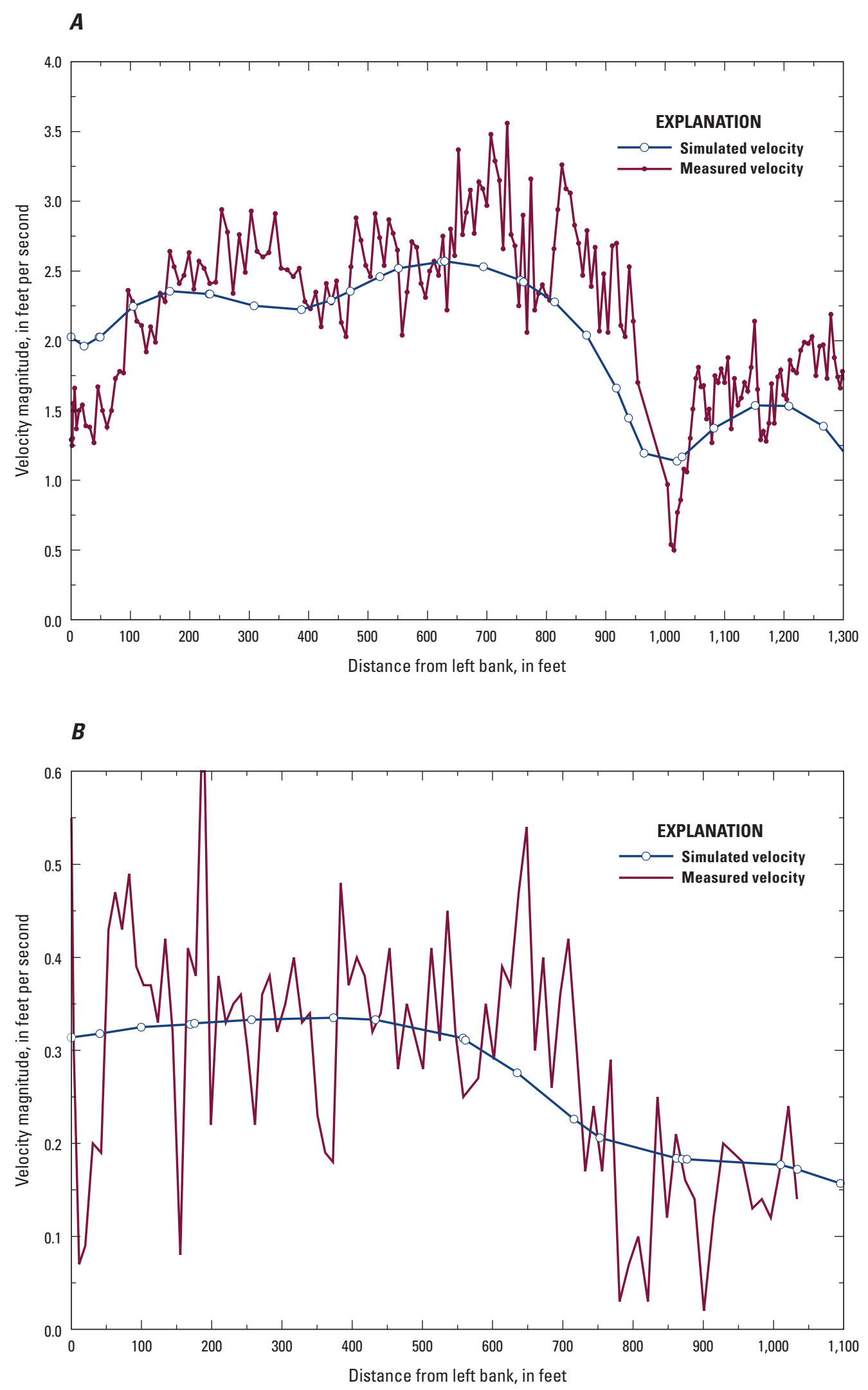

Figure 13. Measured and simulated velocity distributions at cross-sections 17 and 19 directly downstream from Sycamore and NineMile Islands on the Allegheny River, Pool 2 model segment for $A$, high-flow and $B$, low-flow conditions near Pittsburgh, Pennsylvania. 

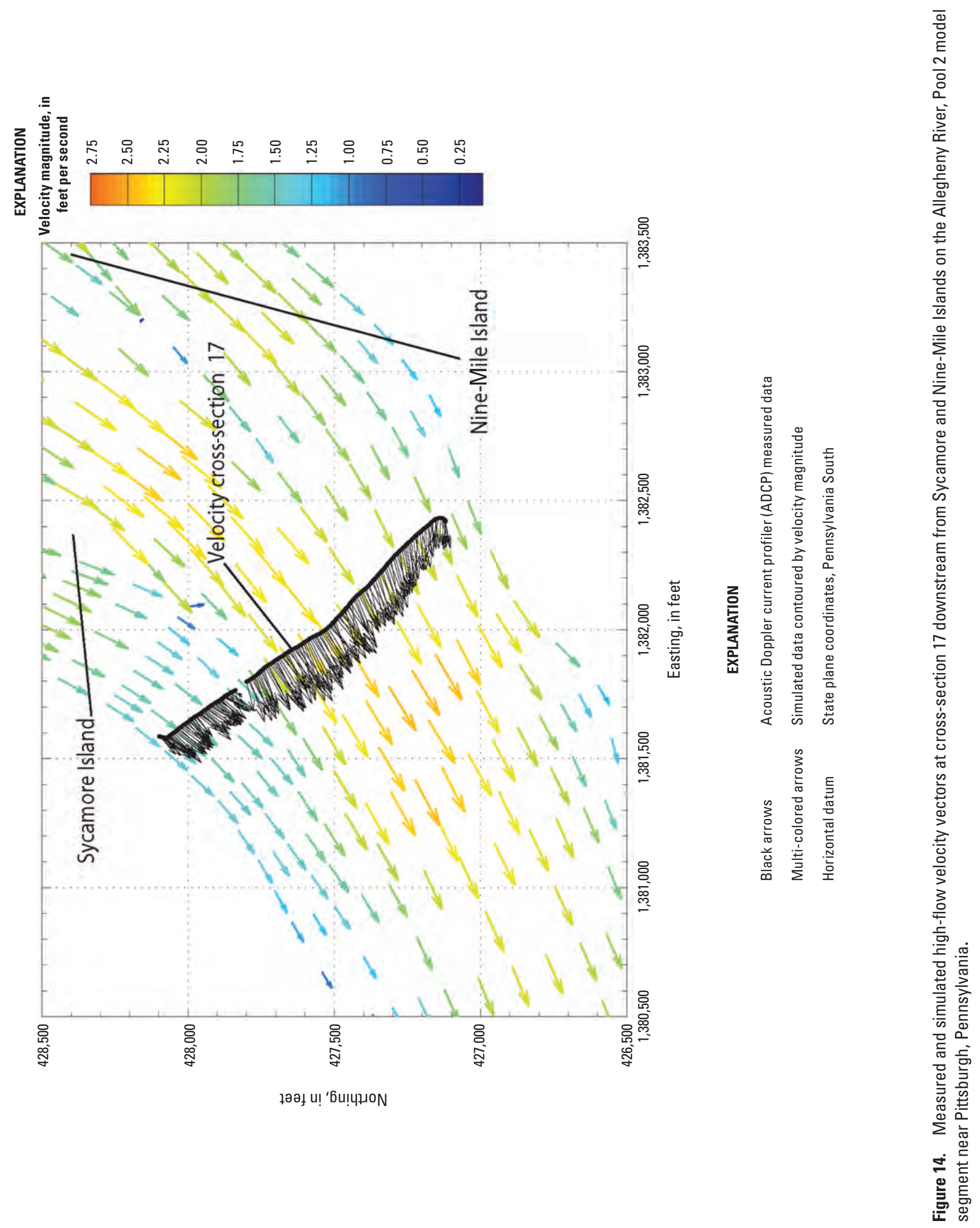


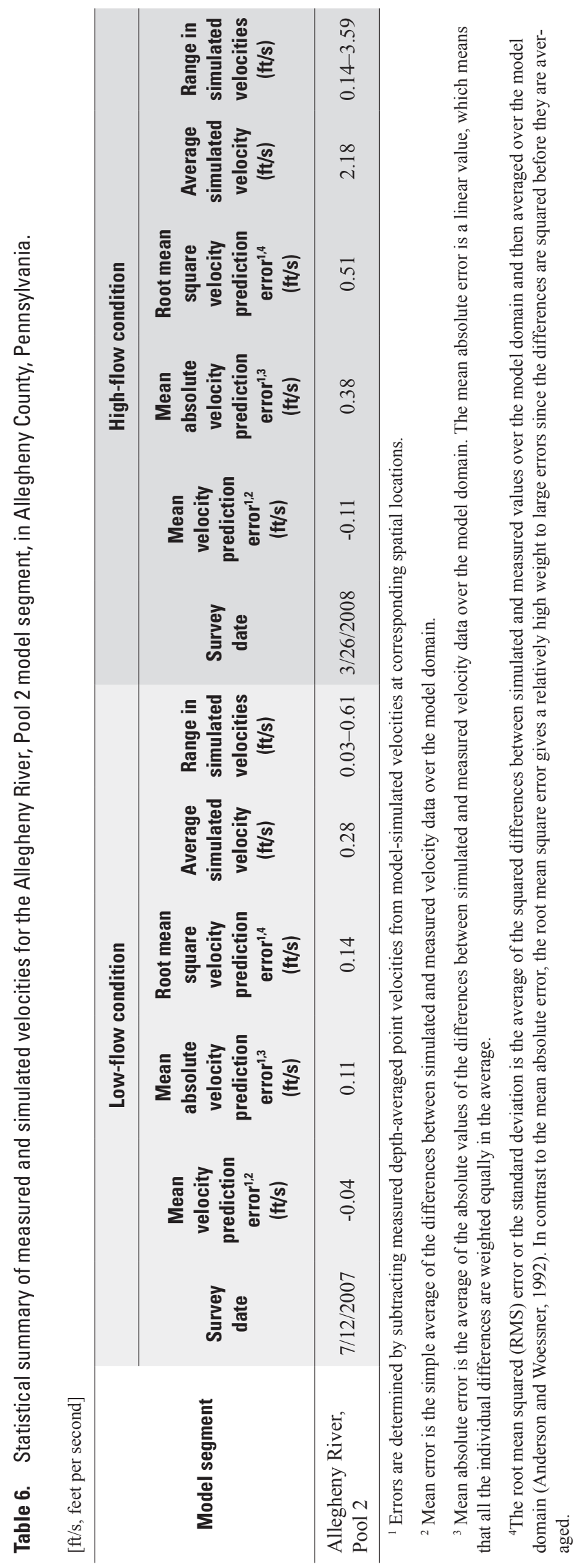



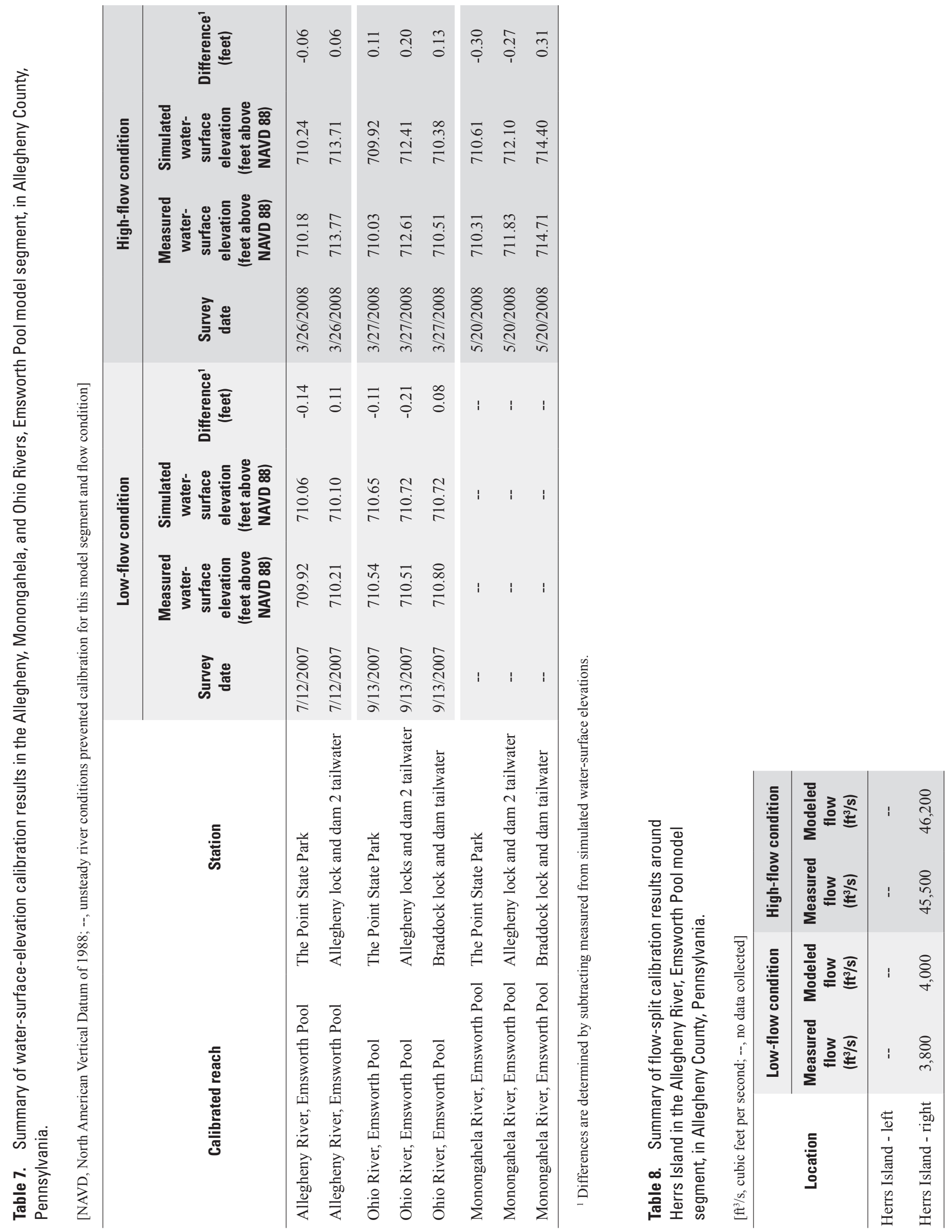

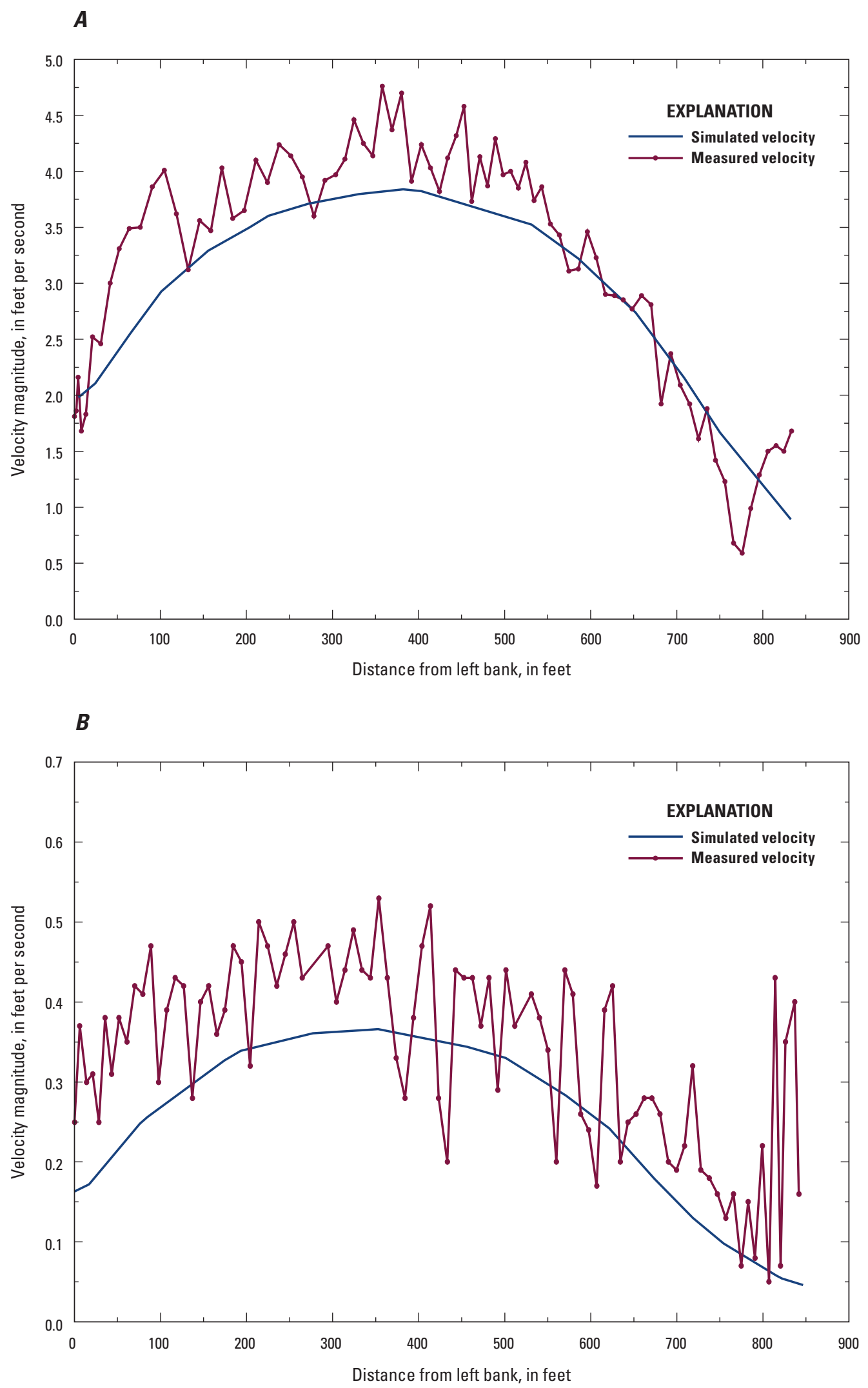

Figure 15. Measured and simulated velocity distributions at cross-sections 4 and 5 directly downstream from Herrs Island on the Allegheny River, Emsworth Pool model segment for $A$, high-flow and $B$, low-flow conditions near Pittsburgh, Pennsylvania. 

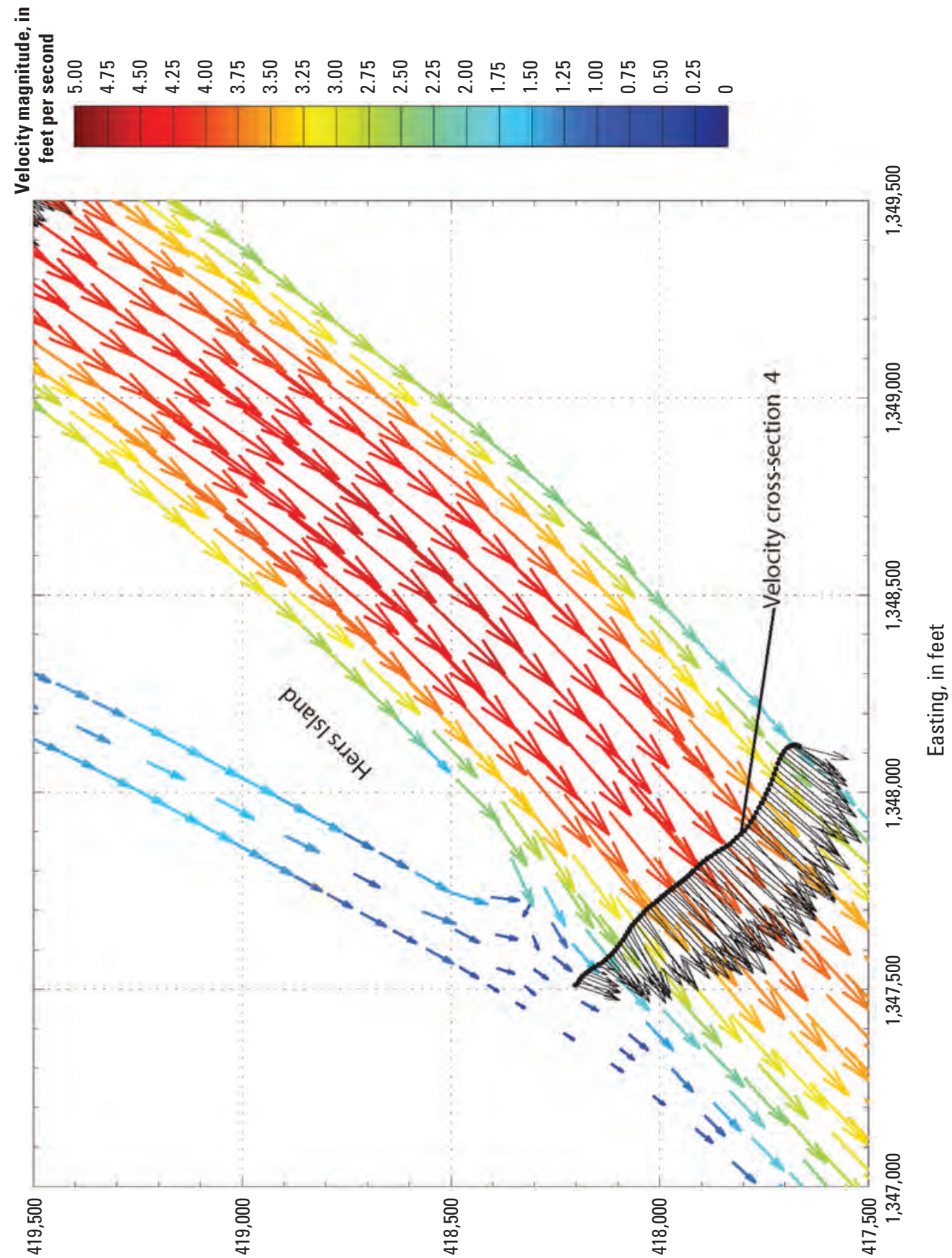

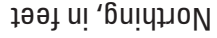

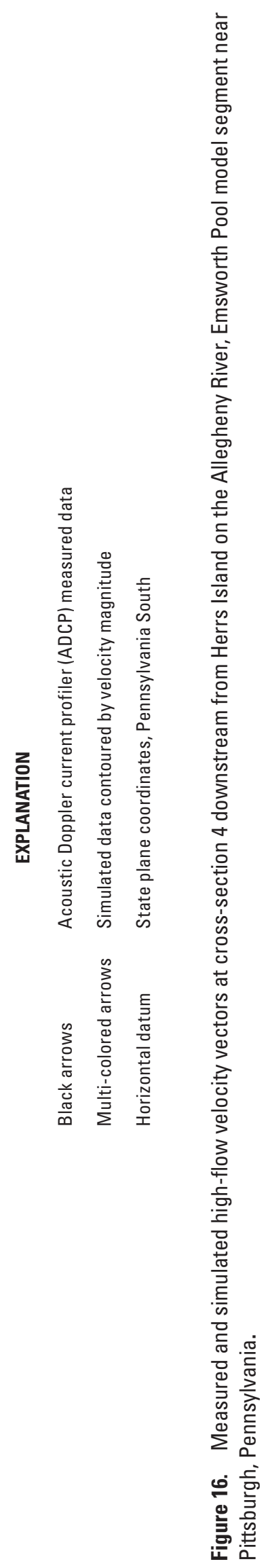




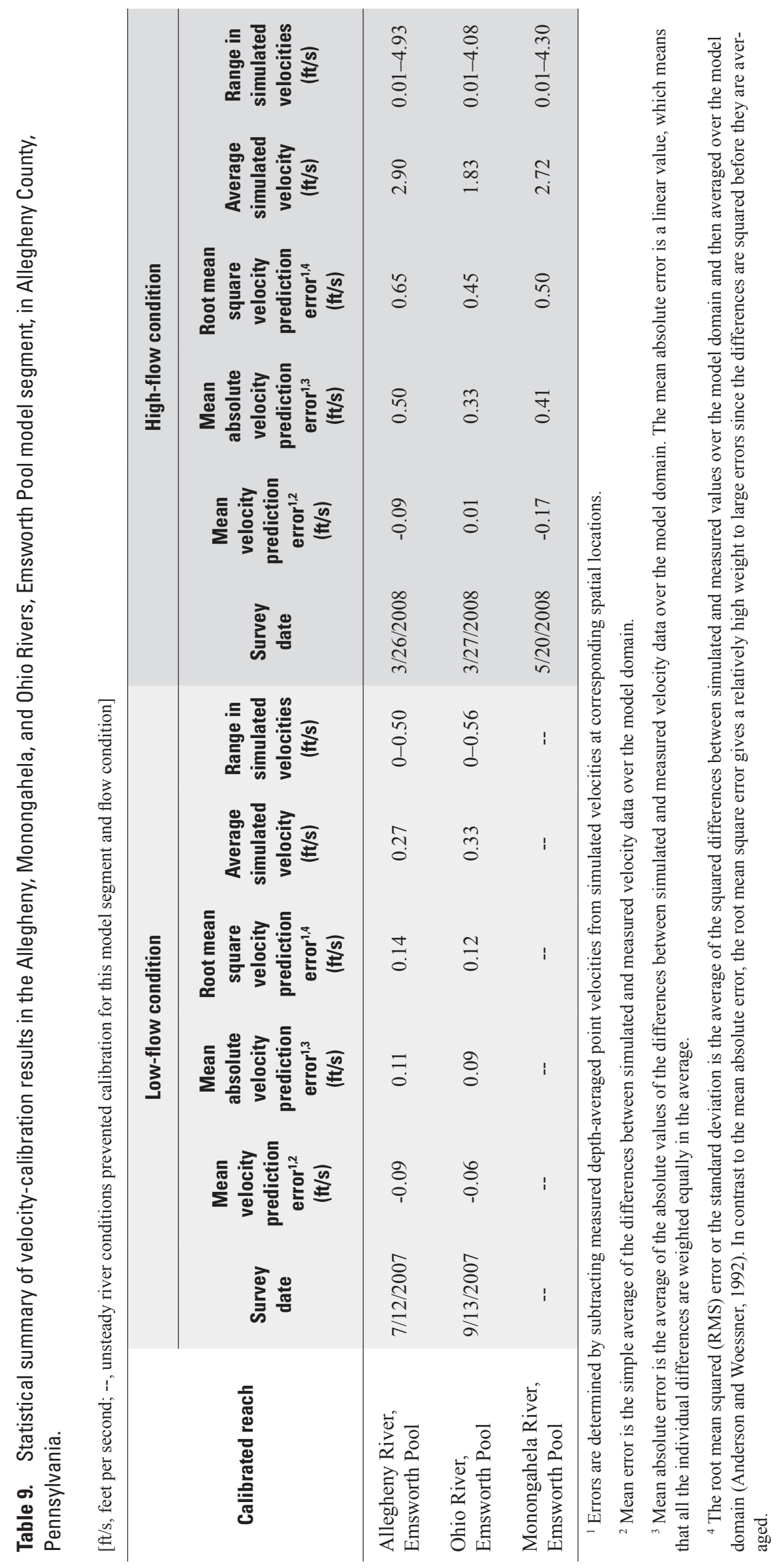




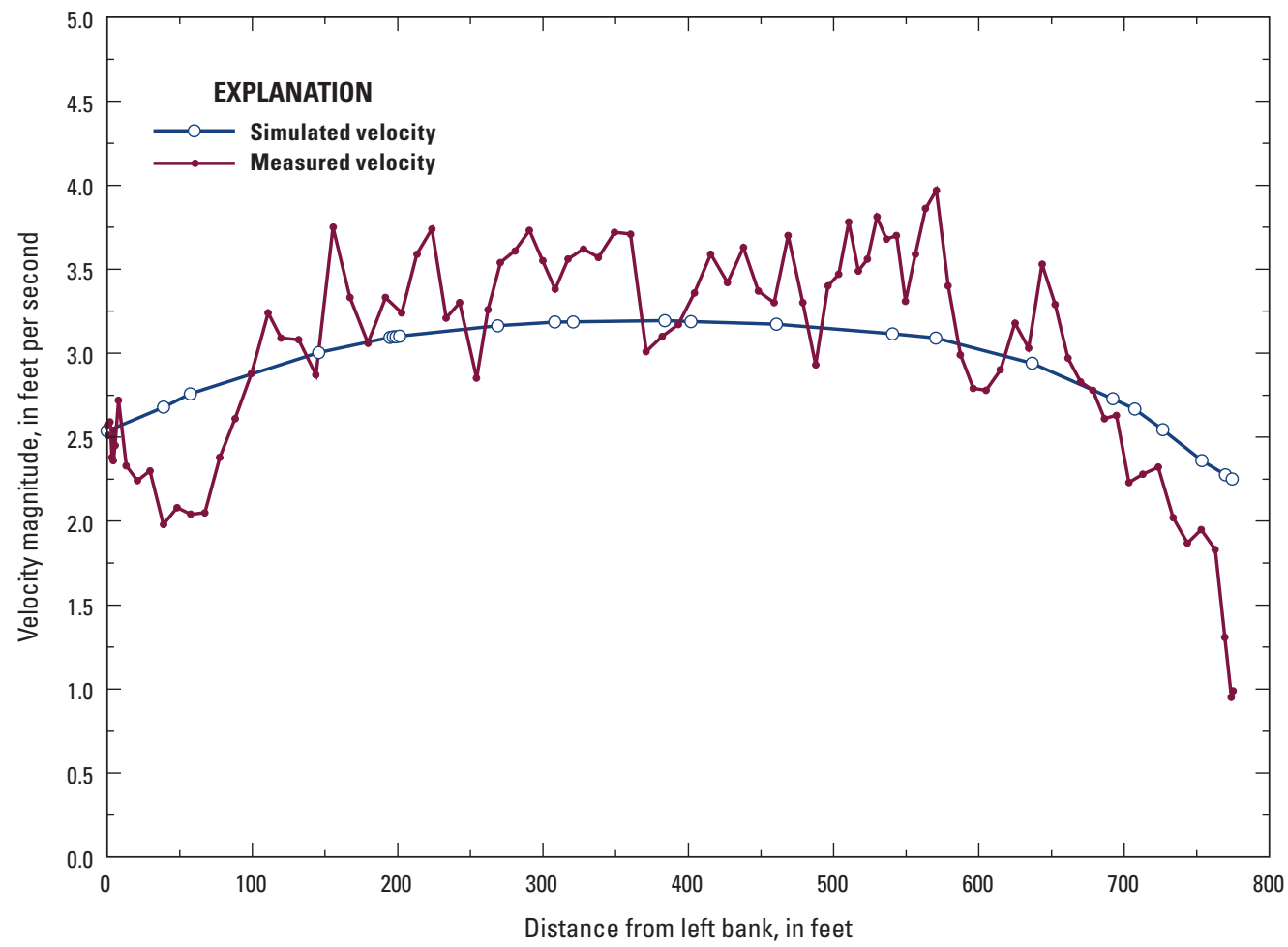

Figure 17. Measured and simulated velocity distributions at cross-section 7 on the Monongahela River, Emsworth Pool model segment for high-flow conditions near Pittsburgh, Pennsylvania.

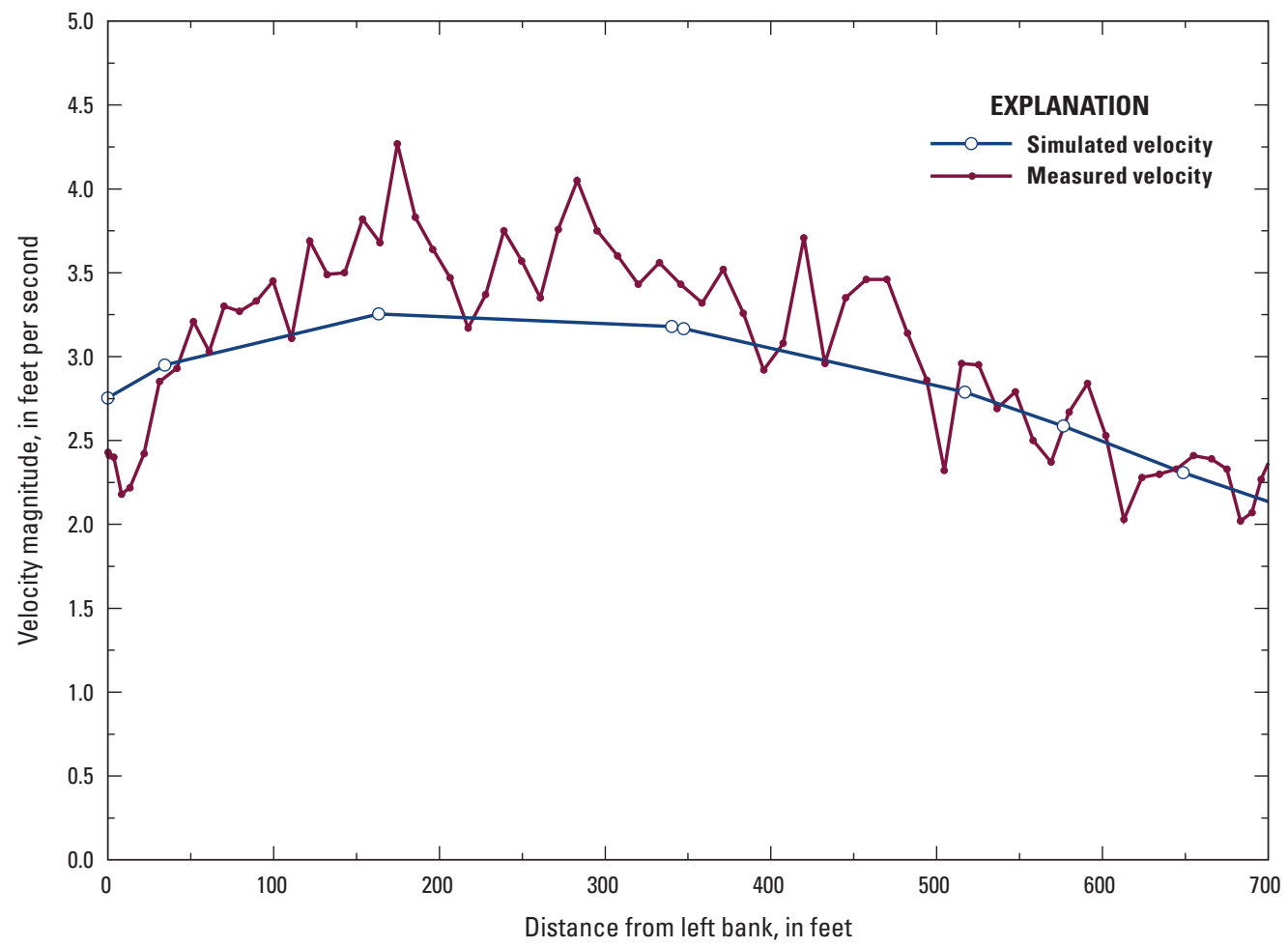

Figure 18. Measured and simulated velocity distributions at cross-section 19 on the Monongahela River, Emsworth Pool model segment for high-flow conditions near Pittsburgh, Pennsylvania. 


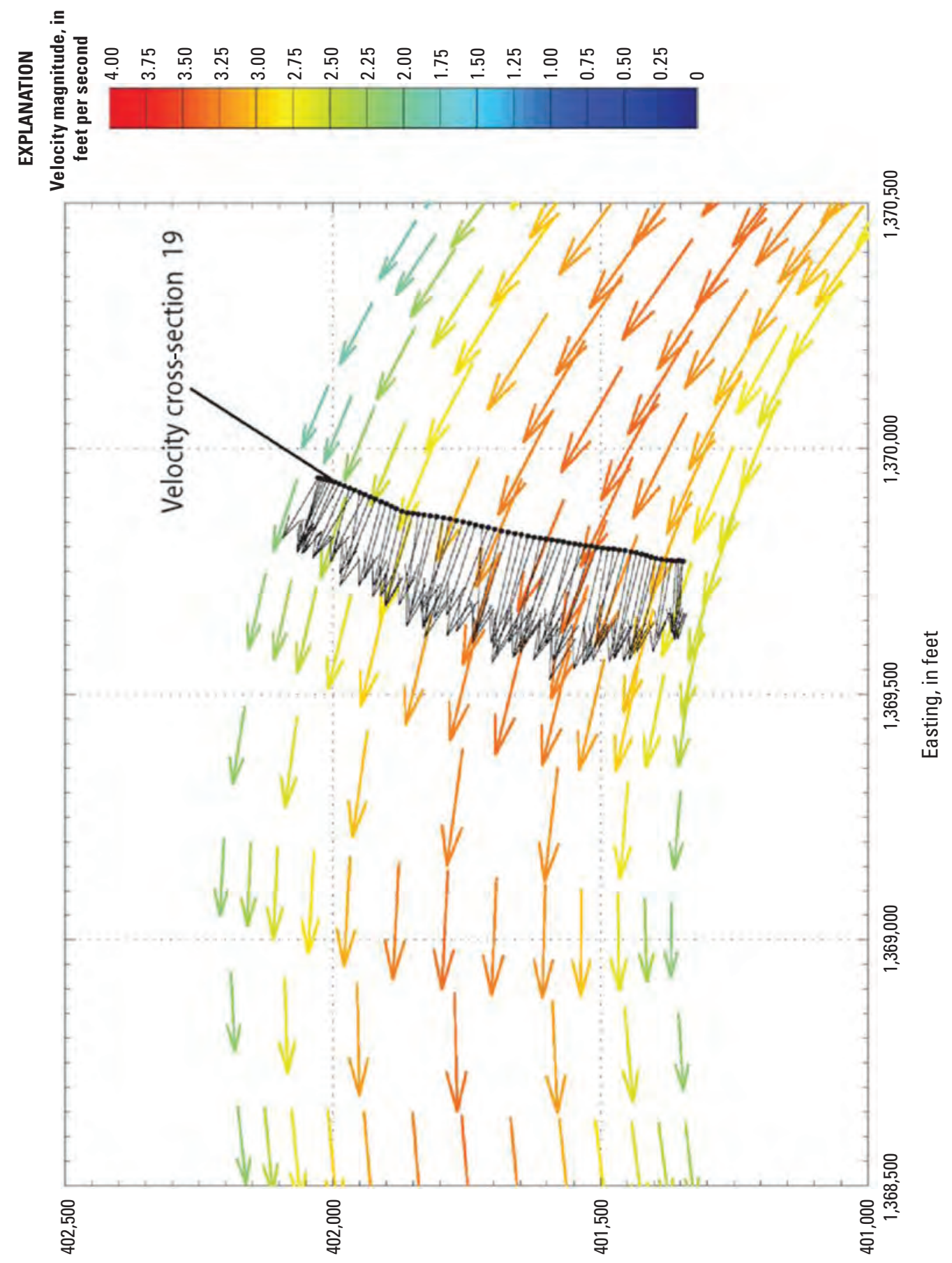

เәәғ น! ‘бu!чนоN

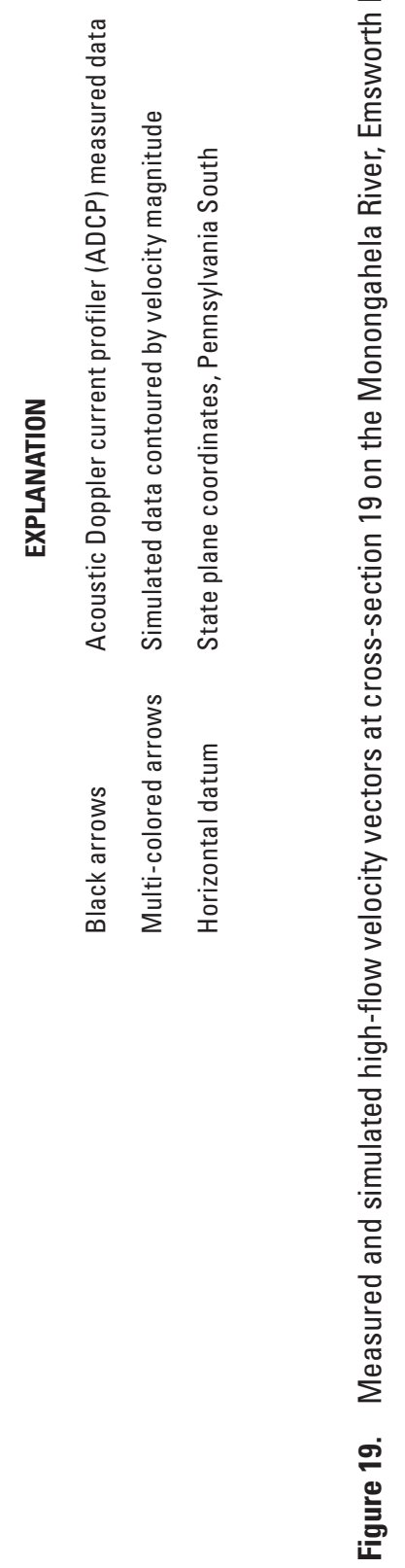


Table 10. Summary of flow-split calibration for islands in the Ohio River, Emsworth Pool model segment, in Allegheny County, Pennsylvania.

[Left and right are in the downstream direction; $\mathrm{ft}^{3} / \mathrm{s}$, cubic feet per second; --, no data collected]

\begin{tabular}{|c|c|c|c|c|}
\hline \multirow[b]{2}{*}{ Location } & \multicolumn{2}{|c|}{ Low-flow condition } & \multicolumn{2}{|c|}{ High-flow condition } \\
\hline & $\begin{array}{c}\text { Measured flow } \\
\left(\mathrm{ft}^{3} / \mathbf{s}\right)\end{array}$ & $\begin{array}{l}\text { Modeled flow } \\
\qquad\left(\mathrm{ft}^{3} / \mathrm{s}\right)\end{array}$ & $\begin{array}{c}\text { Measured flow } \\
\left(\mathrm{ft}^{3} / \mathrm{s}\right)\end{array}$ & $\begin{array}{c}\text { Modeled flow } \\
\left(\mathrm{ft}^{3} / \mathrm{s}\right)\end{array}$ \\
\hline Brunot Island - right & -- & -- & 29,200 & 29,200 \\
\hline Neville Island - main channel & 9,000 & 9,300 & $22,800 *$ & 20,900 \\
\hline Davis Island - right & 630 & 730 & 18,700 & 19,600 \\
\hline Davis Island - left & -- & -- & 7,100 & 6,700 \\
\hline
\end{tabular}

* Modeled total flow is $2,700 \mathrm{ft}^{3} / \mathrm{s}$ less than the instantaneous measured total flow in the river just prior to the measurement of the Emsworth Island main channel.

discharge (representing the mean discharge over the datacollection period) and the measured instantaneous total flow in the river just prior to the measurement of the main channel. The model calibration process consisted of comparing measured and simulated cross-sectional velocity profiles at 9 cross sections for high-flow conditions and 7 cross sections for lowflow conditions in the Ohio River reach of the Emsworth Pool model segment (figs. 9 and 10). Comparisons of the simulatedand measured-velocity profiles for high-flow conditions at cross-section 9 upstream from Brunot Island (fig. 9), high-flow conditions at cross-section 3 upstream from Davis and Neville Islands (fig. 9), and low-flow conditions at cross-section 10 upstream from Davis and Neville Islands (fig. 10) are shown in figure 20 and figure 21, respectively. A comparison of velocity directions and magnitudes for high-flow conditions at cross-sections 9, 1, 2, and 3 are presented in figure 22 and figure 23. Aside from the cross sections measured in the vicinity of tributaries, which exhibited changes in bathymetry with time and were not represented in the model, the shape of the simulated- and measured-velocity distribution and directions compared well. A statistical summary of the measured- and simulated-velocity calibration results is presented in table 9 .

\section{Ohio River, Dashields Pool Calibration Results}

The summary of the water-surface-elevation calibration results for the Ohio River, Dashields Pool, is presented in table 11. Mass was conserved throughout the domain of the Dashields pool model segment to within 0.1 percent for high- and low-flow conditions. The model calibration process consisted of comparing measured and simulated cross-sectional velocity profiles at 4 cross sections for low-flow conditions and at 17 cross sections for high-flow conditions and in the Dashields Pool model segment (figs. 10 and 11). A comparison of the simulated- and measured-velocity profiles for high-flow conditions at cross-section 9 (fig. 11) and low-flow conditions at cross-section 2 (fig. 10) that are directly downstream from Neville Island are shown in figure 24. A comparison of the velocity directions and magnitudes at cross-section 9 (fig. 11) is presented in figure 25. Aside from the cross sections measured in the vicinity of tributaries, which had local areas of changing bathymetry as a function of time that were not represented in the model, the shape of the measured- and simulated-velocity magnitudes and directions compared well. A statistical summary of the measured- and simulated-velocity calibration results is presented in table 12 .

\section{Monongahela River, Braddock Pool Calibration Results}

The Braddock Pool of the Monongahela River was found to be characterized by unsteady flow during low- and high-flow conditions. Despite multiple attempts, steady-state calibration data could not be collected in the reach. Upstream reservoir releases and lockages from Braddock lock and dam caused flow to vary in excess of 100 percent at times during the velocity surveys on the Monongahela River. 


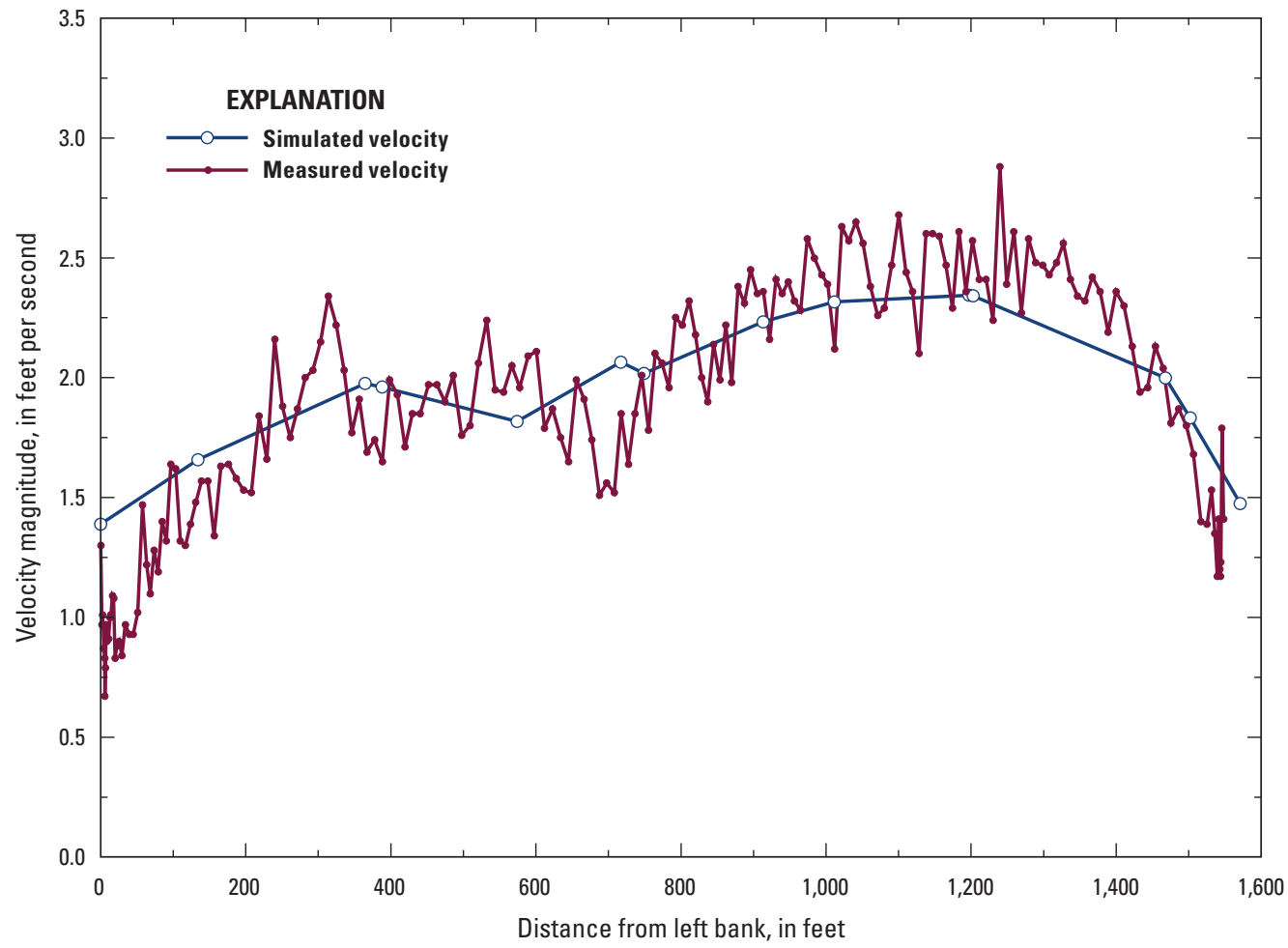

Figure 20. Measured and simulated velocity distributions at cross-section 9 directly upstream from Brunot Island on the Ohio River, Emsworth Pool model segment for high-flow conditions near Pittsburgh, Pennsylvania. 

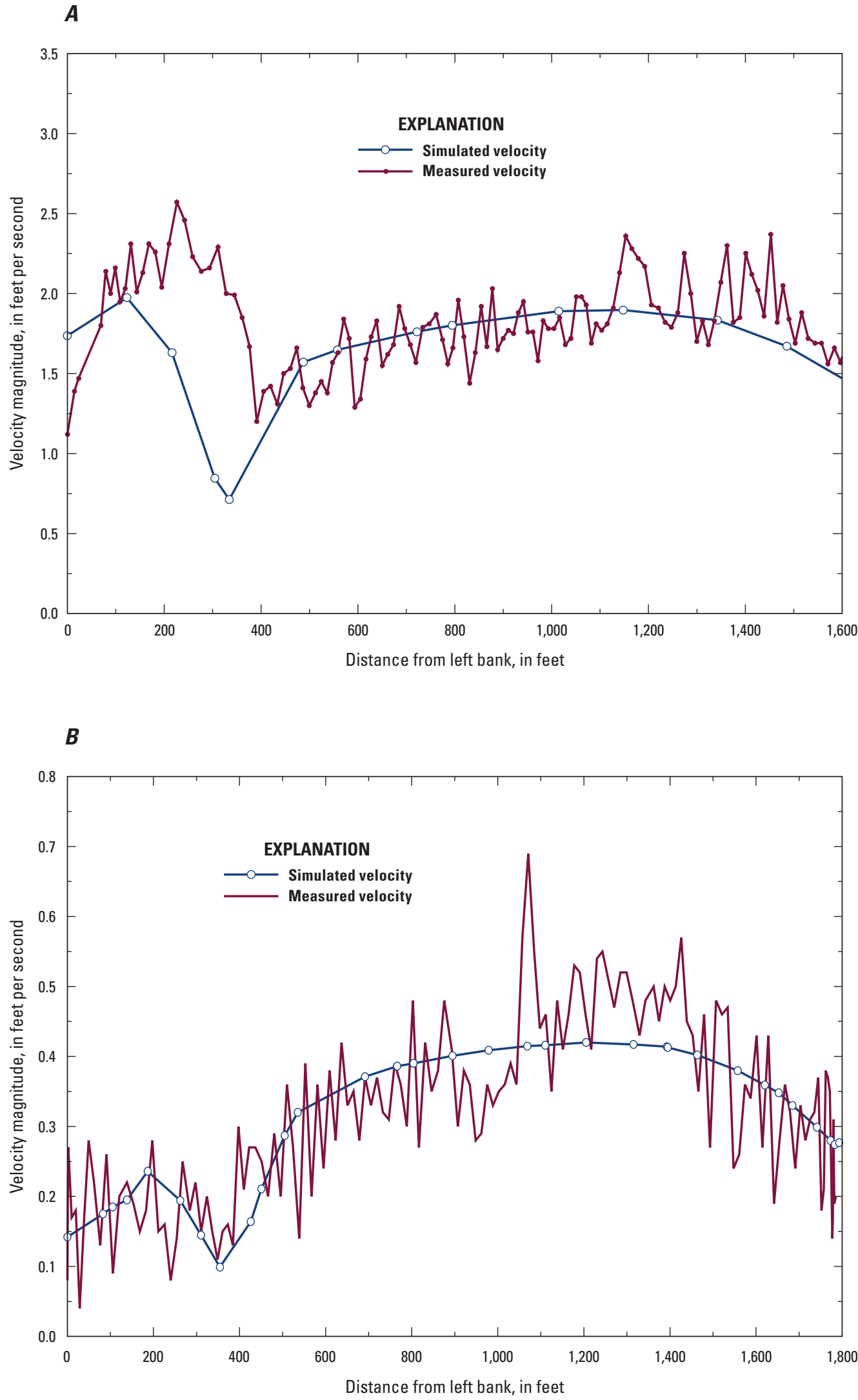

Figure 21. Measured and simulated velocity distributions at cross-sections 3 and 10 directly upstream from Neville and Davis Islands on the Ohio River, Emsworth Pool model segment for $A$, high-flow and $B$, low-flow conditions near Pittsburgh, Pennsylvania. 

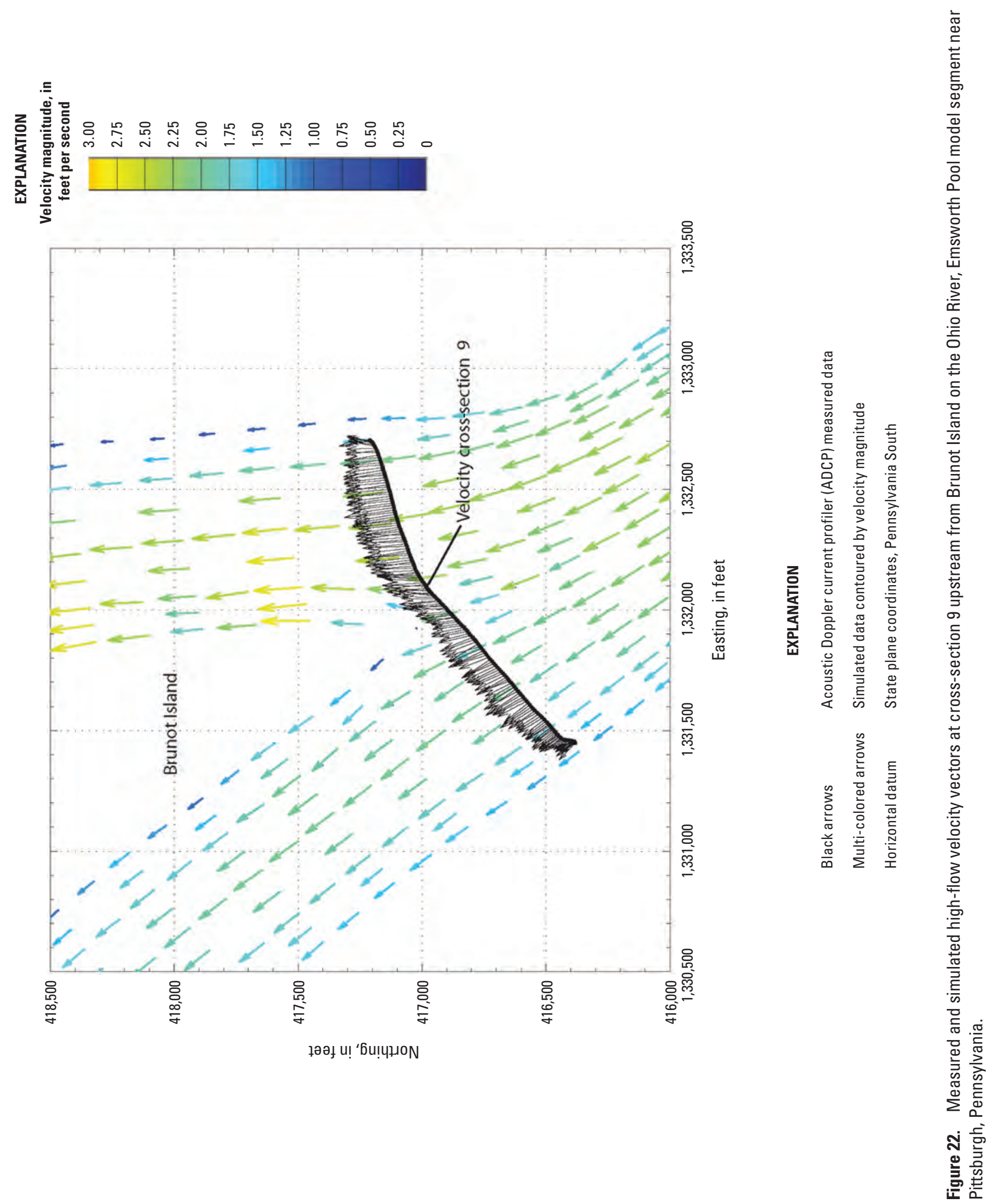


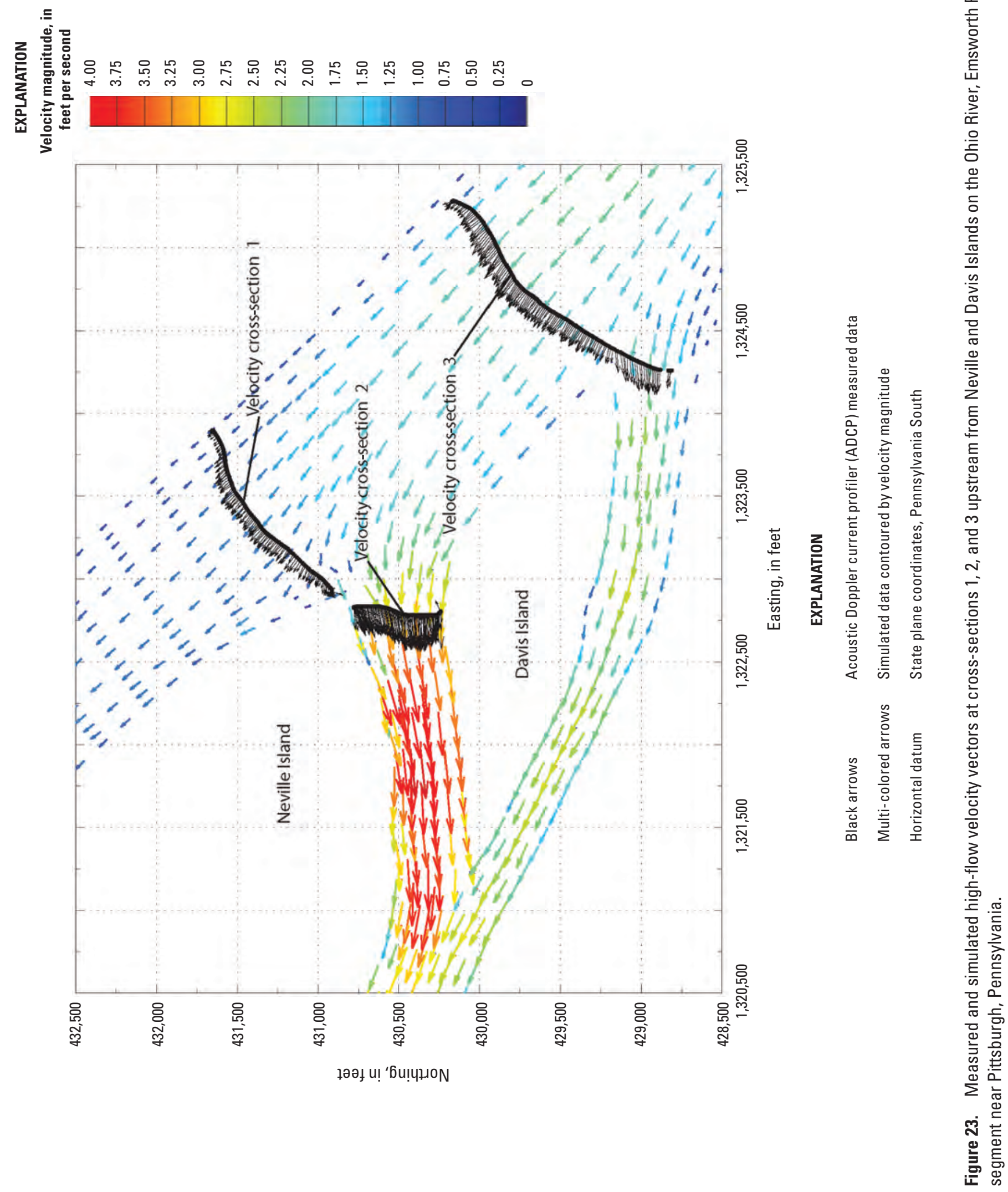



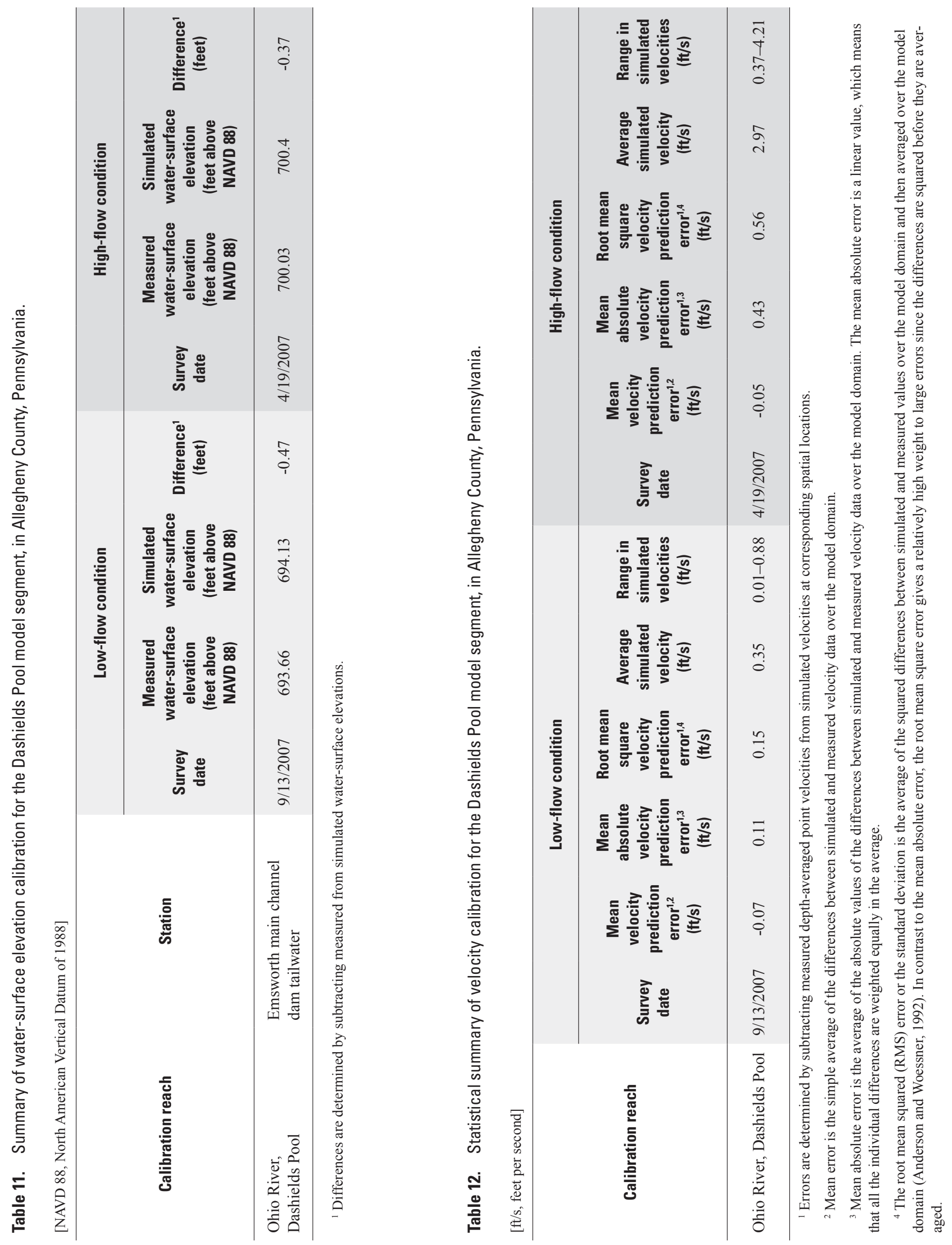

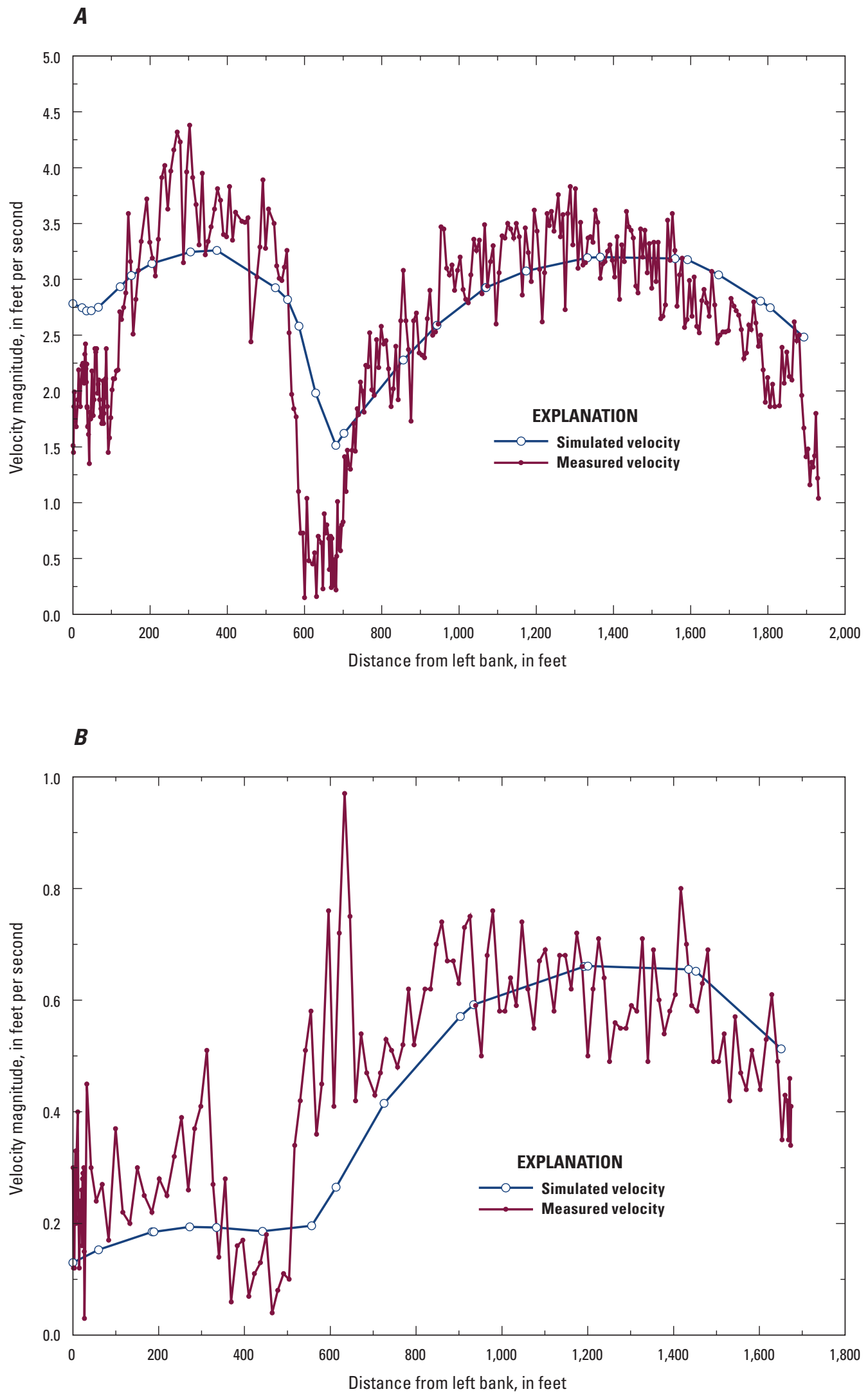

Figure 24. Measured and simulated velocity distributions at cross-sections 9 and 2 directly downstream from Neville Island on the Ohio River, Dashields Pool model segment for $A$, high-flow and $B$, low-flow conditions near Pittsburgh, Pennsylvania. 

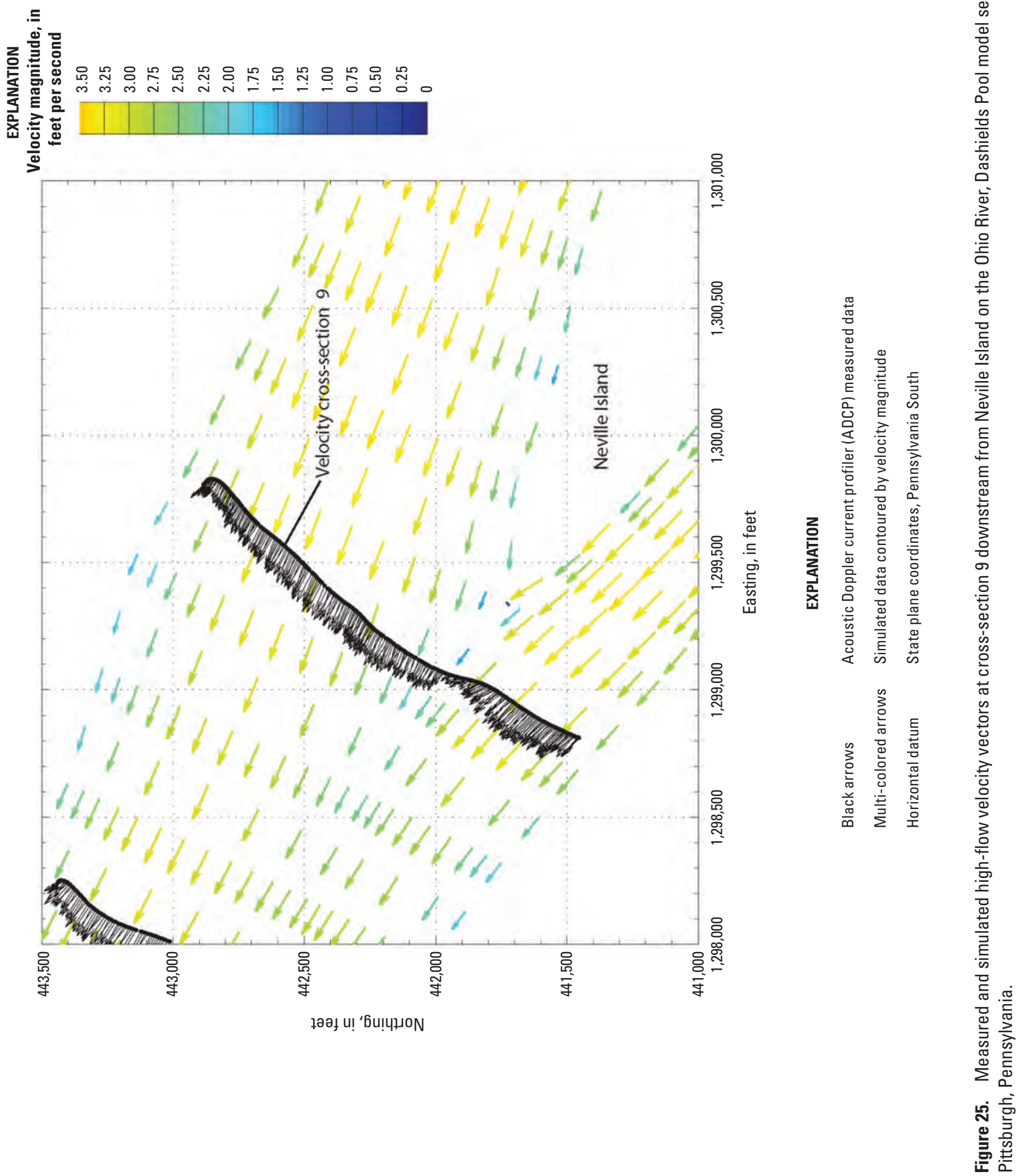


\section{Model Uncertainty}

Hydrodynamic models require three types of data: (1) bathymetric and topographic data for the hydrodynamic model computational grid, (2) effective friction values (Manning's $n$ ) and eddy viscosity terms for each computational element, and (3) model validation data of some type (Bates and others, 2004). Uncertainties exist in each of these data types (Bales and others, 2006). In fact, the unsteady streamflow resulting from operation of the navigation locks and dams and lack of gate ratings for the locks and dams in the study area made calibration impossible for some parts of the Three Rivers model.

\section{Bathymetric Data}

Channel bathymetry of the Three Rivers was surveyed from a moving boat at approximately one section per every channel width. Despite the dense bathymetric data, uncertainty is introduced during the creation of a continuous bathymetric map of the channel from cross-sectional data. Surveyed bathymetric data do not fall on perfectly straight cross sections because of inconsistencies in the boat course across the river. Internal triangulation routines by the RMA2 interface software package Surface-water Modeling System (SMS) documented by Aquaveo (2012) did not properly interpolate the collected bathymetric data to the computational mesh (Wagner and Mueller, 2001). Instead, a uniform grid of the raw bathymetric data was developed using the channel template routine included in International River Interface Cooperative ( iRIC) User's Manual (2012); this grid was used to build the computational mesh. The data used to build the computational mesh are an interpolated representation of the raw bathymetric data, which introduces model uncertainty, especially in the areas between measured cross sections and the region between the measured bathymetric point closest to each bank and the corresponding bank point. Uncertainty also exists in bathymetric data for the small parts of the tributaries that were included in the model. For most of the tributaries, bathymetric data were not available, and the main channel bathymetric data collected in the vicinity of the tributary were used to estimate the bathymetry in the tributaries near the confluences with the Three Rivers main channels.

In addition, differences in measured and simulated velocity magnitudes can partially be attributed to variations in channel bathymetry that occurred in the 2 years between collection of the bathymetric data and completion of the calibration-datacollection surveys. During those 2 years, bathymetric data in the study reach indicated riverbed aggradation and degradation in response to variations in flow patterns and potential anthropogenic influences.

\section{Hydraulic Parameters}

Friction values (Manning's n) and Peclet values (eddy viscosity) were assigned to the model on the basis of engineering judgment and in accordance with published literature (Chow, 1988; Wagner and Mueller, 2001; Wagner and Mueller, 2002). Given that the coarse mesh configuration was six elements wide, the single row of elements with raised Manning's $n$ values along the edges to simulate increased bank roughness could be representing a larger part of the river than is realistic.

\section{Model Calibration Data}

The hydraulic complexities imposed by the locks-anddam configuration, gates and fixed-head dams, and reservoir regulation contributed to unsteady flow throughout the Three Rivers study area. For example, the Allegheny River receives releases from eight reservoirs, and pool elevations are maintained by eight fixed-crest dams extending from river mile 0.0 at the Point at Pittsburgh to river mile 72, north of East Brady, $\mathrm{Pa}$. The Monongahela River receives releases from three reservoirs, and pool elevations are maintained by two fixed-crest and seven gated dams extending from river mile 0.0 at the Point at Pittsburgh to river mile 115.4, near Fairmont, W.Va. The Ohio River receives releases from four reservoirs and is controlled by six locks and dams that provide navigable waters from the Point at Pittsburgh 127.2 mi downstream to New Martinsville, W.Va. Locations of locks and dams in the Three Rivers study area are shown in figure 1.

The unsteadiness of flow introduced uncertainty into the comparisons of velocity distributions and flow splits around islands and even precluded the collection of calibration data for the Monongahela River Emsworth pool under low-flow conditions and for Braddock pool under low- and high-flow conditions.

Velocity profiles collected with the ADCP include random noise associated with the measurement of the Doppler shift off moving particles in the water column. Random noise associated with Doppler measurements of velocity are accentuated during low-flow conditions. This random noise can result in unrealistic velocities, which need to be screened and can add to the uncertainty of the velocity data used for model calibration and validation. 


\section{Summary and Conclusions}

A hydrodynamic model has been developed for parts of the Allegheny, Monongahela, and Ohio Rivers (Three Rivers) in Allegheny County, Pennsylvania. The hydraulic characteristics of the Three Rivers are dominated by the operation of several U.S. Army Corps of Engineers (USACE) reservoirs, locks, and dams. Approximately 90 percent of the total reservoir storage is dedicated to managing water quality; however, the release schedule has a profound effect on the velocity distribution and magnitude of streamflow in the Allegheny and Monongahela River systems entering Allegheny County. The determination of flow patterns is an essential component of a water-quality model in a riverine environment. Therefore, it is critical for the hydrodynamic model to be calibrated to represent field measurements.

The U.S. Geological Survey (USGS) developed, calibrated, and validated a two-dimensional hydrodynamic model capable of quantifying flow patterns that could be used as inputs to the water-quality model of the Three Rivers in Allegheny County, Pa., prepared by ALCOSAN. Bathymetric surveys were conducted to determine the channel geometry and develop the computational grid for the model. The model was separated into four segments on the basis of the USACE navigational pools in the study area (Dashields; Emsworth; Allegheny River, Pool 2; and Braddock). To the extent possible, each model segment was calibrated for both high- and low-streamflow conditions by matching water-surface elevations at five locations and velocity profiles at more than 80 cross sections in the study area. The simulated low-flow water-surface elevations typically were within 0.2 feet (ft) of measured values, whereas the simulated high-flow watersurface elevations were typically within $0.3 \mathrm{ft}$ of the measured values. The mean error between simulated and measured velocities was less than $0.07 \mathrm{ft} / \mathrm{s}$ for low-flow conditions and less than $0.17 \mathrm{ft} / \mathrm{s}$ for high-flow conditions.

The integrated hydrodynamic prepared by the USGS and water-quality model developed by ALCOSAN of the Three Rivers study area can be used to (1) evaluate alternatives for treating combined sewer overflow and sanitary sewer overflow discharged to the Three Rivers during dry- and wet-weather events and (2) determine the relative significance of dry- and wet-weather overflows on the receiving waters within the Three Rivers. Relevant RMA2 files will be stored in the USGS Pennsylvania Water Science Center digital model archive and will be made available upon request.

\section{References Cited}

Anderson, M.P. and Woessner, W.M., 1992, Applied Groundwater Modeling, Simulation of Flow and Advective Transport, Academic Press, Inc., San Diego, CA.

Aquaveo, 2012, Surface-water modeling solution, accessed October 20, 2012 at http://www.aquaveo.com/sms.

Bales, J.D., Wagner, C.R., Cassingham, K. and Terziotti, S., 2006, Flood inundation maps for real-time flood mapping applications, Tar River Basin, North Carolina: U.S. Geological Survey Scientific Investigations Report 2007-5032, $34 \mathrm{p}$.

Bates, P.D., Wilson, M.D., Horritt, M.S., Mason, D.C., Holden, N., and Currie, A., 2004, Remote sensing and flood inundation modeling: Hydrological Processes, v. 18, p. 2593-2597.

Chow, V.T., 1988 (reissued), Open-channel Hydraulics, New York, McGraw-Hill, 680 p.

Donnell, B.P., Letter, J.V., McAnally, W.H., and others, 2011, Users guide for RMA2 WES version 4.5: U.S. Army, Engineer Research and Development Center, Waterways Experiment Station, Coastal and Hydraulics Laboratory, accessed June 25, 2012, at http://chl.erdc.usace.army.mil/ Media/3/2/7/Rma2_v45_Users_Guide_09-27-2011.pdf.

Fulton, J.W., and Buckwalter, T.F., 2004, Fecal-indicator bacteria in the Allegheny, Monongahela, and Ohio Rivers, near Pittsburgh, July-September 2001: U.S. Geological Survey Scientific Investigations Report 2004-5009, 39 p.

iRIC, 2012, User's Manual, accessed October 31, 2012, at http://i-ric.org/en/download/get/EZeSVL.

Letter, J.V., Donnell, B.P., and others, 2011, Users guide for RMA4 WES version 4.5: U.S. Army, Engineer Research and Development Center, Waterways Experiment Station, Coastal and Hydraulics Laboratory, accessed June 25, 2012, at $h t t p: / / c h l . e r d c . u s a c e . a r m y . m i l / M e d i a / 3 / 2 / 7 / R m a 2 \_v 45$ Users_Guide_09-27-2011.pdf.

Mueller, D.S., and Wagner, C.R., 2009, Measuring discharge with acoustic Doppler current profilers from a moving boat: U.S. Geological Survey Techniques and Methods 3A-22, 72 p. (Also available at http://pubs.water.usgs.gov/tm3a2.2.) 
National Research Council, Committee on Water Quality Improvement for the Pittsburgh Region, 2005, Regional cooperation for water quality improvement in southwestern Pennsylvania: Washington, D.C., National Research Council of the National Academies, The National Academies Press, $282 \mathrm{p}$.

Pennsylvania Code, Title 25, Environmental protection, Chapter 93. Water quality standards, Section 93.7., Specific water quality criteria (25PaCode $\S 93.7$ ), accessed October 30 , 2012, at http://www.pacode.com/secure/data/025/chapter93/ s93.7.html.

Simpson, M.R., and Oltmann, R.N., 1991, Discharge-measurement system using an Acoustic Doppler Current Profiler with applications to large rivers and estuaries: U.S. Geological Survey Water-Resources Investigations Report 91-487, $49 \mathrm{p}$.

Turnipseed, D.P., and Sauer, V.B., 2010, Discharge measurements at gaging stations: U.S. Geological Survey Techniques and Methods book 3, chap. A8, 87 p. (Also available at $h t t p: / / p u b s . u s g s . g o v / t m / t m 3-a 8 /$.

U.S. Army Corps of Engineers, 2006, Water management: Pittsburgh, Pa., U.S. Army Corps of Engineers, Pittsburgh District, accessed November 1, 2006, at http://www.lrp. usace.army.mil/org/who.htm\#water.

U.S. Army Corps of Engineers, 1997a, Allegheny River Navigational Charts, Pittsburgh, Pa. to East Brady, Pa.: U.S. Army Corps of Engineers, Pittsburgh District, 68 p.

U.S. Army Corps of Engineers, 1997b, Monongahela River Navigational Charts, Pittsburgh, Pa. to Fairmont, W. Va.: U.S. Army Corps of Engineers, Pittsburgh District, 100 p.

U.S. Army Corps of Engineers, 1999, Ohio River Navigational Charts, Pittsburgh, Pa. to Martinsville, W. Va.: U.S. Army Corps of Engineers, Pittsburgh District, 112 p.

U.S. Geological Survey, 2012, National Water Information System, accessed October 31, 2012, at http://waterdata. usgs.gov/pa/nwis/.

Wagner, C.R., and Mueller, D.S., 2002, Use of velocity data to calibrate and validate two-dimensional hydrodynamic models, in Proceedings of the Second Federal Interagency Hydrologic Modeling Conference, Las Vegas, NV, July 29 - August 1, 2002: Subcommittee on Hydrology of the Interagency Advisory Committee on Water Information.
Wagner, C.R., and Mueller, D.S., 2001, Calibration and validation of a two-dimensional hydrodynamic model of the Ohio River, Jefferson County, Kentucky: U.S. Geological Survey Water-Resources Investigations Report 01-4091, 33 p. 
Prepared by the West Trenton Publishing Service Center

For additional information, write to:

Director

U.S. Geological Survey

Pennsylvania Water Science Center

215 Limekiln Road

New Cumberland, PA 17070

or visit our Web site at:

http://pa.water.usgs.gov/ 


\section{$\frac{\mathbb{3}}{\mathbb{3}}$}

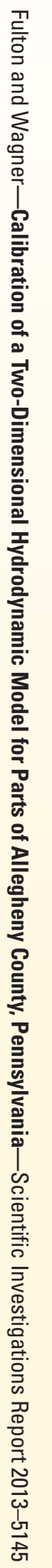

